\title{
LEVEL II SCOUR ANALYSIS FOR BRIDGE 11R (ROCKTH0001011R) on TOWN HIGHWAY 1 (VT 121, FAS 125), crossing the SAXTONS RIVER, ROCKINGHAM, VERMONT
}

U.S. Geological Survey Open-File Report 97-345

Prepared in cooperation with

VERMONT AGENCY OF TRANSPORTATION and

FEDERAL HIGHWAY ADMINISTRATION 


\section{LEVEL II SCOUR ANALYSIS FOR BRIDGE 11R (ROCKTH0001011R) on TOWN HIGHWAY 1 (VT 121, FAS 125), crossing the SAXTONS RIVER, ROCKINGHAM, VERMONT}

By Erick M. Boehmler

U.S. Geological Survey Open-File Report 97-345

Prepared in cooperation with

VERMONT AGENCY OF TRANSPORTATION and

FEDERAL HIGHWAY ADMINISTRATION

Pembroke, New Hampshire 


\title{
U.S. DEPARTMENT OF THE INTERIOR BRUCE BABBITT, Secretary
}

\author{
U.S. GEOLOGICAL SURVEY \\ Gordon P. Eaton, Director
}

For additional information write to:

District Chief

U.S. Geological Survey 361 Commerce Way

Pembroke, NH 03275-3718
Copies of this report may be purchased from:

U.S. Geological Survey

Branch of Information Services

Open-File Reports Unit

Box 25286

Denver, CO 80225-0286 


\section{CONTENTS}

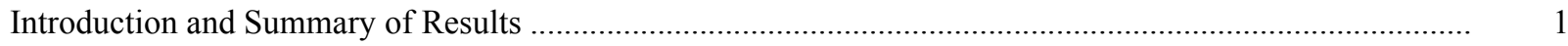

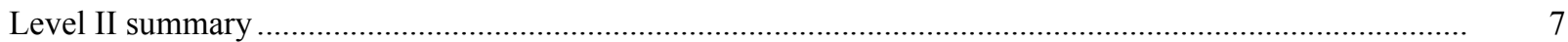

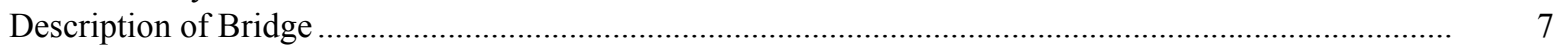

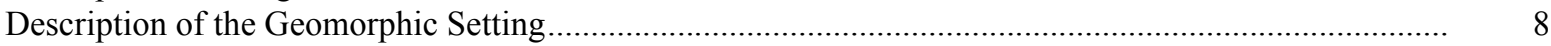

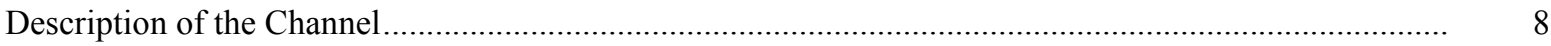

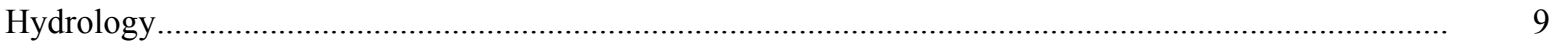

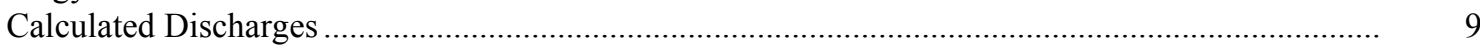

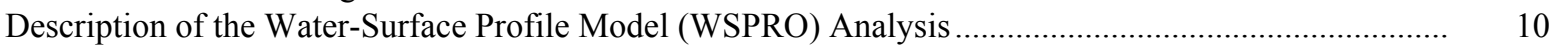

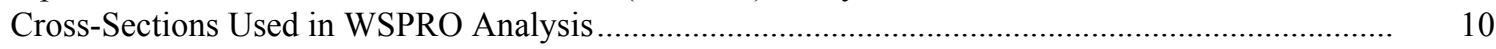

Data and Assumptions Used in WSPRO Model ...................................................................... 11

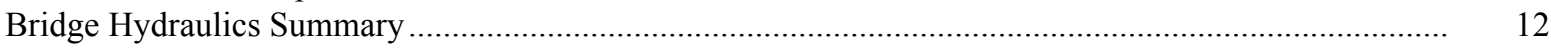

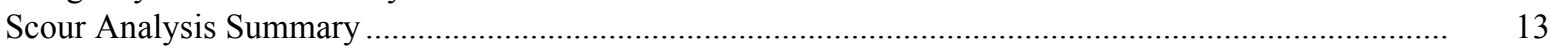

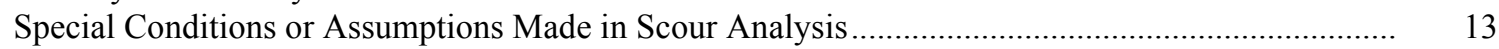

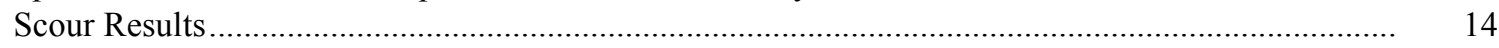

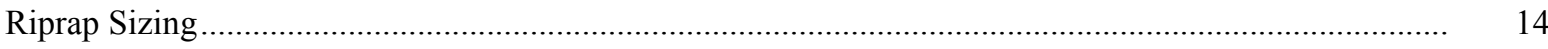

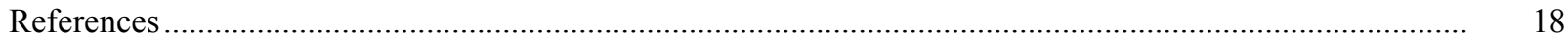

Appendixes:

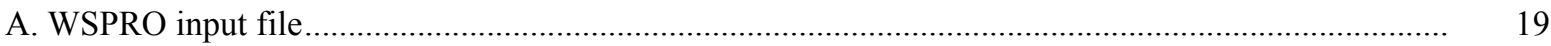

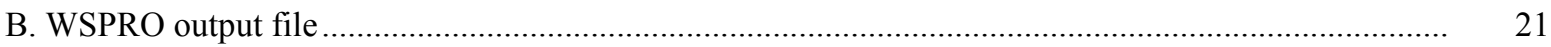

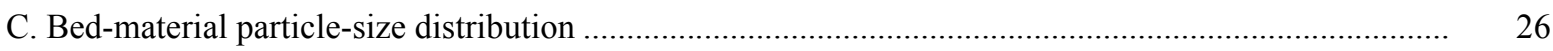

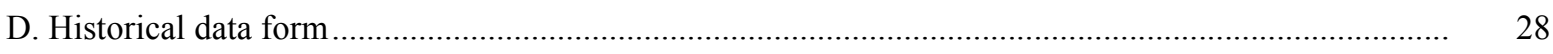

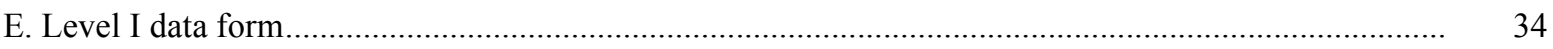

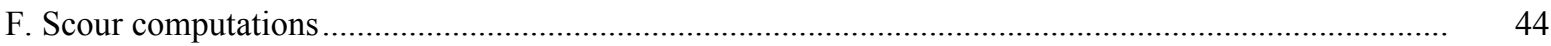

\section{FIGURES}

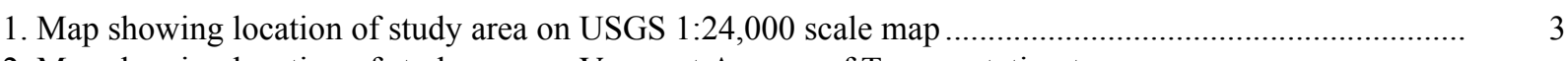

2. Map showing location of study area on Vermont Agency of Transportation town

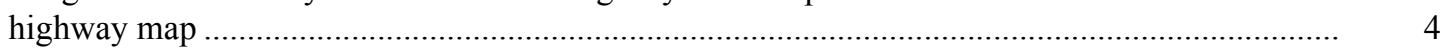

3. Structure ROCKTH0001011R viewed from upstream (September 3, 1996) .......................................... 5

4. Downstream channel viewed from structure ROCKTH0001011R (September 3, 1996)......................... 5

5. Upstream channel viewed from structure ROCKTH0001011R (September 3, 1996).................................. 6

6. Structure ROCKTH0001011R viewed from downstream (September 3, 1996).................................... 6

7. Water-surface profiles for the 100- and 500-year discharges at structure

ROCKTH0001011R on Town Highway 1, crossing the Saxtons River,

Rockingham, Vermont.

8. Scour elevations for the 100- and 500-year discharges at structure

ROCKTH0001011R on Town Highway 1, crossing the Saxtons River,

Rockingham, Vermont.

\section{TABLES}

1. Remaining footing/pile depth at abutments for the 100-year discharge at structure

ROCKTH0001011R on Town Highway 1, crossing the Saxtons River,

Rockingham, Vermont

2. Remaining footing/pile depth at abutments for the 500-year discharge at structure

ROCKTH0001011R on Town Highway 1, crossing the Saxtons River,

Rockingham, Vermont

(

5

6

6




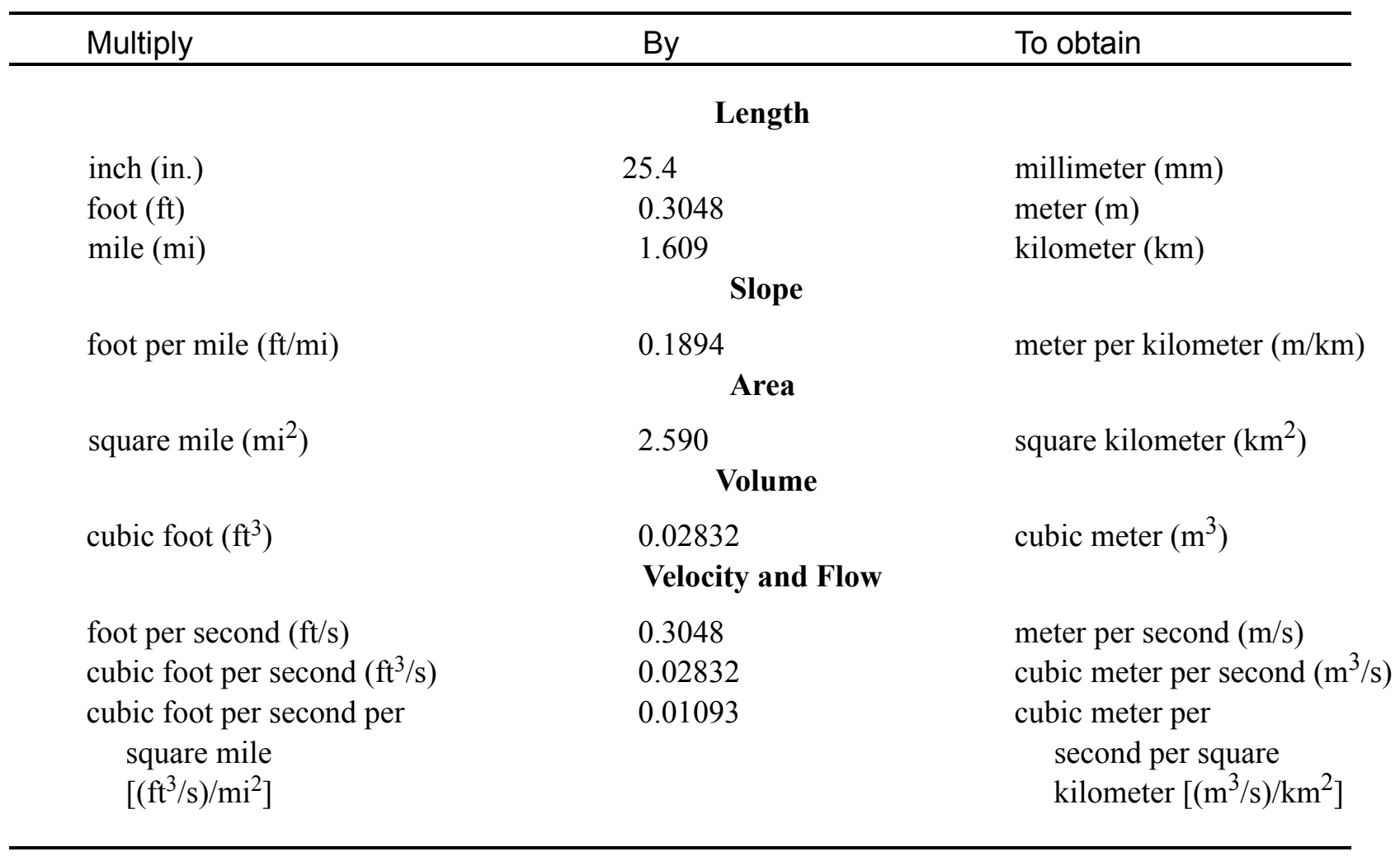

\section{OTHER ABBREVIATIONS}

$\begin{array}{lrlr}\mathrm{BF} & \text { bank full } & \text { LWW } & \text { left wingwall } \\ \mathrm{cfs} & \text { cubic feet per second } & \text { MC } & \text { main channel } \\ \mathrm{D}_{50} & \text { median diameter of bed material } & \text { RAB } & \text { right abutment } \\ \mathrm{DS} & \text { downstream } & \text { RABUT } & \text { face of right abutment } \\ \mathrm{elev} & \text { elevation } & \text { RB } & \text { right bank } \\ \mathrm{f} / \mathrm{p} & \text { flood plain } & \text { ROB } & \text { right overbank } \\ \mathrm{ft}^{2} & \text { square feet } & \text { RWW } & \text { right wingwall } \\ \mathrm{ft} / \mathrm{ft} & \text { feet per foot } & \text { TH } & \text { town highway } \\ \mathrm{JCT} & \text { junction } & \text { UB } & \text { under bridge } \\ \mathrm{LAB} & \text { left abutment } & \text { US } & \text { upstream } \\ \mathrm{LABUT} & \text { face of left abutment } & \text { USGS } & \text { United States Geological Survey } \\ \mathrm{LB} & \text { left bank } & \text { VTAOT Vermont Agency of Transportation } \\ \mathrm{LOB} & \text { left overbank } & \text { WSPRO } & \text { water-surface profile model }\end{array}$

In this report, the words "right" and "left" refer to directions that would be reported by an observer facing downstream. Sea level: In this report, "sea level" refers to the National Geodetic Vertical Datum of 1929-- a geodetic datum derived from a general adjustment of the first-order level nets of the United States and Canada, formerly called Sea Level Datum of 1929.

In the appendices, the above abbreviations may be combined. For example, USLB would represent upstream left bank. 


\title{
LEVEL II SCOUR ANALYSIS FOR BRIDGE 11R (ROCKTH0001011R) ON TOWN HIGHWAY 1, (VT121, FAS 125) CROSSING THE SAXTONS RIVER, ROCKINGHAM, VERMONT
}

\author{
By Erick M. Boehmler
}

\section{INTRODUCTION AND SUMMARY OF RESULTS}

This report provides the results of a detailed Level II analysis of scour potential at structure ROCKTH0001011R on Town Highway 1 crossing the Saxtons River, Rockingham, Vermont (figures 1-8). A Level II study is a basic engineering analysis of the site, including a quantitative analysis of stream stability and scour (U.S. Department of Transportation, 1993). Results of a Level I scour investigation also are included in Appendix E of this report. A Level I investigation provides a qualitative geomorphic characterization of the study site. Information on the bridge, gleaned from Vermont Agency of Transportation (VTAOT) files, was compiled prior to conducting Level I and Level II analyses and is found in Appendix D.

The site is in the New England Upland section of the New England physiographic province in southeastern Vermont. The $68.3-\mathrm{mi}^{2}$ drainage area is in a predominantly rural and forested basin. In the vicinity of the study site, the surface cover consists of houses, short grass, and scattered trees except along the immediate river banks, which are tree covered.

In the study area, the Saxtons River has a sinuous channel with a slope of approximately $0.005 \mathrm{ft} / \mathrm{ft}$, an average channel top width of $121 \mathrm{ft}$ and an average bank height of $8 \mathrm{ft}$. The predominant channel bed materials are gravel and cobbles with a median grain size $\left(\mathrm{D}_{50}\right)$ of $109 \mathrm{~mm}(0.359 \mathrm{ft})$. The geomorphic assessment at the time of the Level I and Level II site visit on September 3, 1996, indicated that the reach was laterally unstable. Lateral instability was evident with respect to a cut-bank on the left bank upstream with slip failure of bank material. Furthermore, there is a wide point bar along the right bank upstream opposite the cut-bank.

The Town Highway 1 crossing of the Saxtons River is a 184-ft-long, two-lane bridge consisting of three steel-beam spans (Vermont Agency of Transportation, written communication, March 30, 1995). The bridge is supported by vertical, concrete, skeletalstyle abutment walls with spill-through embankments adjacent to each wall. The channel is skewed approximately 35 degrees to the opening while the opening-skew-to-roadway is 30 degrees. 
The only scour protection measure at the site was type-3 stone fill (less than 48 inches diameter) on the spill-through embankments. Additional details describing conditions at the site are included in the Level II Summary and Appendices D and $\mathrm{E}$.

Scour depths and rock rip-rap sizes were computed using the general guidelines described in Hydraulic Engineering Circular 18 (Richardson and others, 1995). Total scour at a highway crossing is comprised of three components: 1) long-term streambed degradation; 2) contraction scour (due to accelerated flow caused by a reduction in flow area at a bridge) and; 3) local scour (caused by accelerated flow around piers and abutments). Total scour is the sum of the three components. Equations are available to compute depths for contraction and local scour and a summary of the results of these computations follows.

There was no computed contraction scour for all modelled flows at this site. Abutment scour ranged from 9.0 to 13.4 feet. The worst-case abutment scour occurred at the 500 -year discharge for the left abutment. There are two piers for which computed pier scour ranged from 9.0 to 18.4 feet. The left and right piers in this report are presented as pier 1 and pier 2, respectively. The worst-case pier scour occurred at pier 2 for the 500-year discharge. Additional information on scour depths and depths to armoring are included in the section titled "Scour Results". Scoured-streambed elevations, based on the calculated scour depths, are presented in tables 1 and 2. A cross-section of the scour computed at the bridge is presented in figure 8 . Scour depths were calculated assuming an infinite depth of erosive material and a homogeneous particle-size distribution.

It is generally accepted that the Froehlich equation (abutment scour) gives "excessively conservative estimates of scour depths" (Richardson and others, 1995, p. 47). Usually, computed scour depths are evaluated in combination with other information including (but not limited to) historical performance during flood events, the geomorphic stability assessment, existing scour protection measures, and the results of the hydraulic analyses. Therefore, scour depths adopted by VTAOT may differ from the computed values documented herein. 


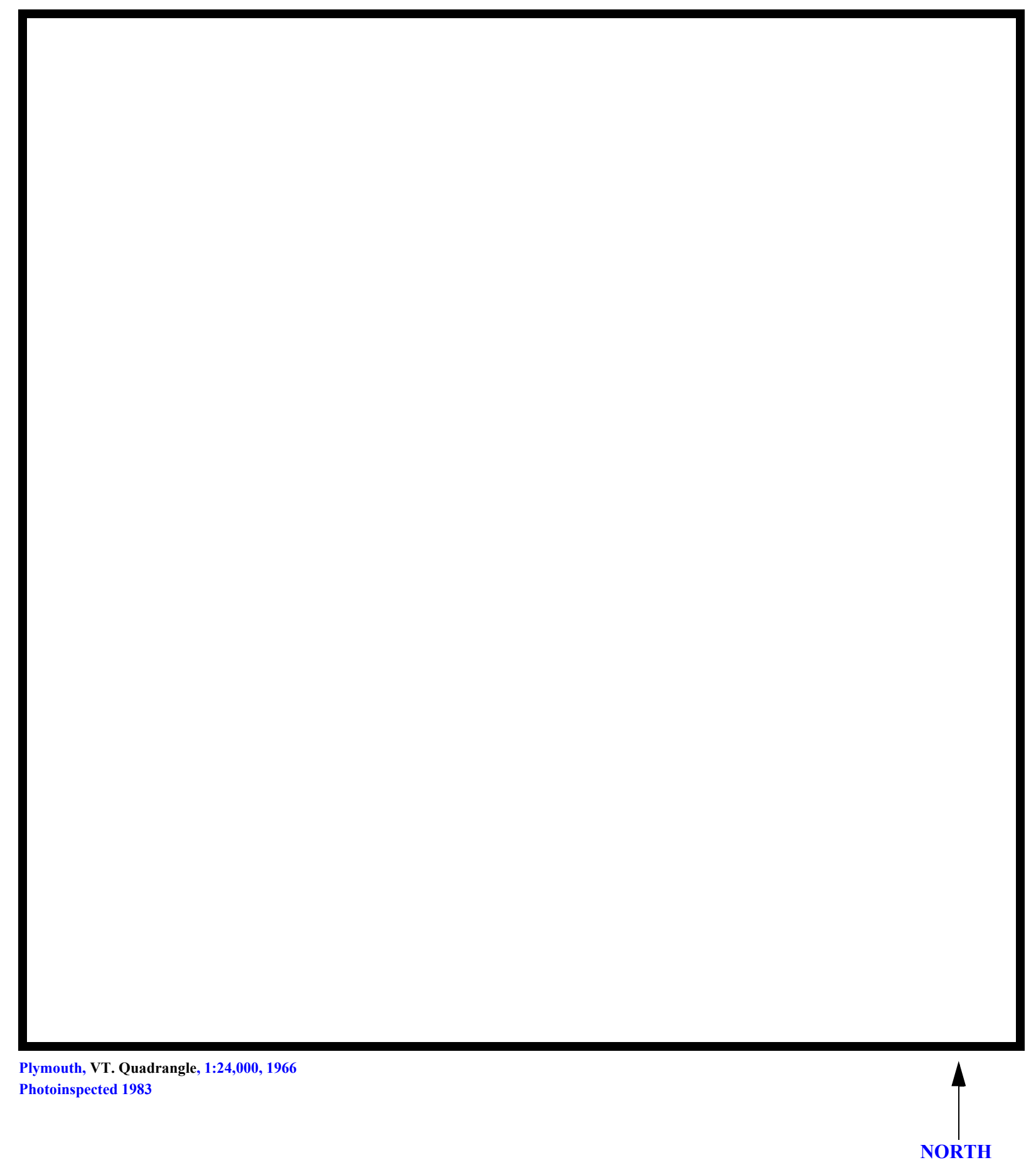

Figure 1. Location of study area on USGS 1:24,000 scale map. 
Figure 2. Location of study area on Vermont Agency of Transportation town highway map. 

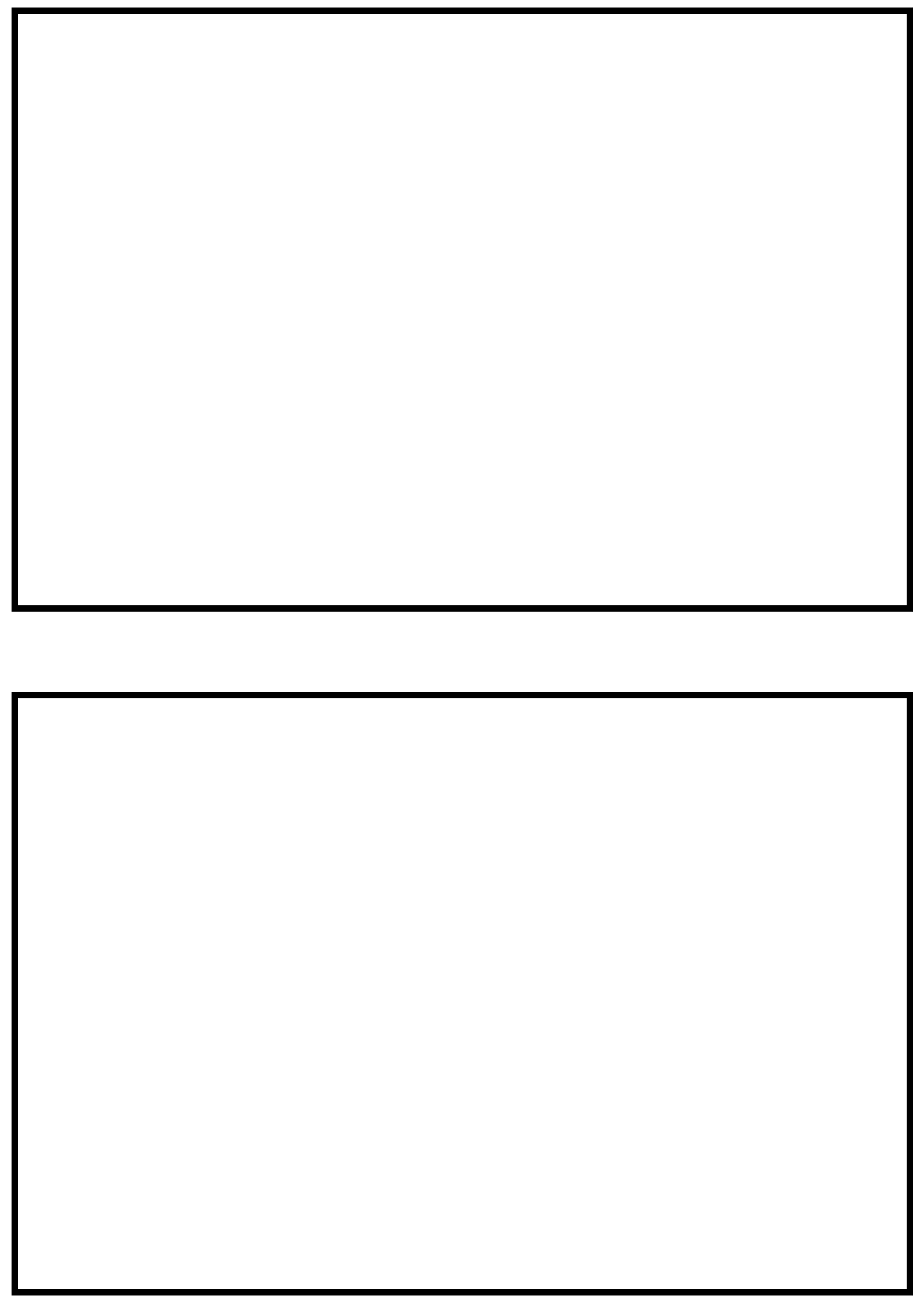

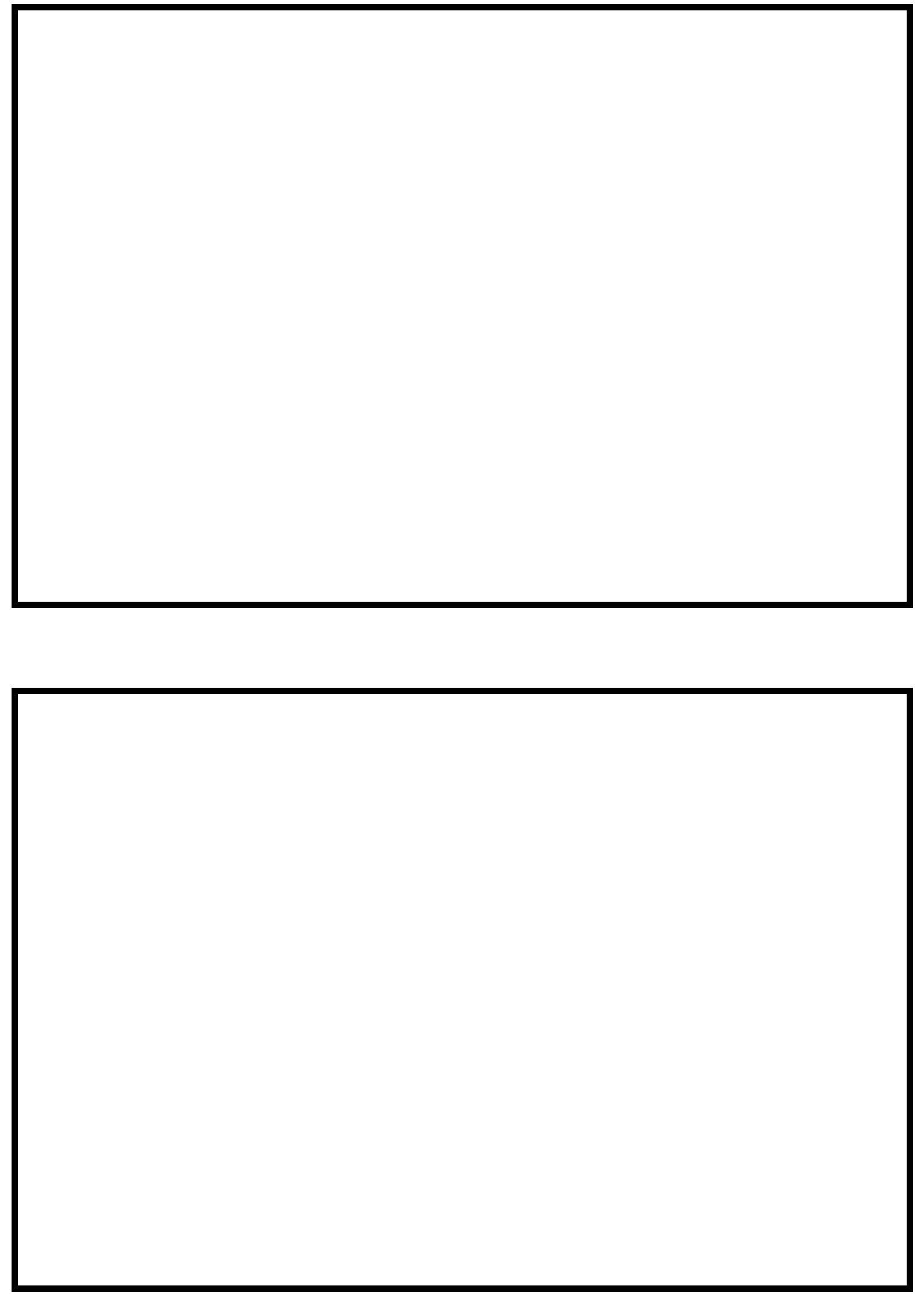


\section{LEVEL II SUMMARY}

\begin{tabular}{llllll} 
Structure Number & ROCKTH0001011R & & \multicolumn{3}{c}{ Saxtons River } \\
Stream & & & \\
County & Windham & Road & TH 1 & District & 2
\end{tabular}

\section{Description of Bridge}

Bridge length $\frac{184}{f t} \quad$ Bridge width $\frac{39.0}{f t} \quad$ Max span length $\frac{69}{f t}$ Alignment of bridge to road (on curve or straight)

Abutment type Spill-through

Stone fill on abutment?

Nacnuintine. af atom a fill

$$
\text { Yes }
$$

\section{Embankment type}

Straight, left; Curve, right

Sloping

Dato af incmortinn
Type- 3 on the spill-through embankments adjacent to each abutment

wall.

Abutments are concrete, skeletal style walls with spill-

through embankments. Piers are solid concrete and are wider and longer at the streambed than at the bridge seat elevation.

Yes

35

Is bridge skewed to flood flow according to Yes ' survey?

Angle

There is a mild_channel bend in the upstream reach.

Debris accumulation on bridge at time of Level I or Level II site visit:

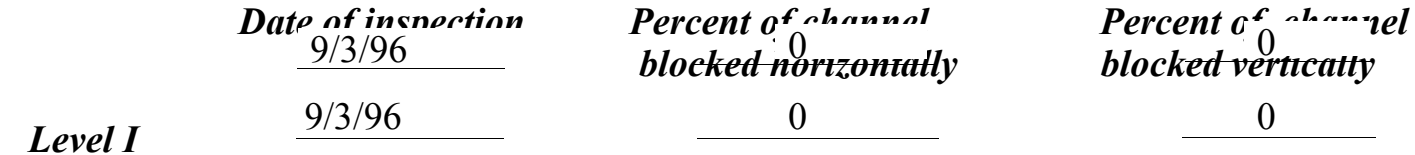

Level II

Moderate. There is dense tree cover on the banks upstream and the channel is laterally unstable.

Potential for debris

None noted on 9/3/96

Doscriho anv foaturos noar ar at tho hridoo that mav, affort flow, (includo ahsorvation dato) 


\section{Description of the Geomorphic Setting}

General topography The channel is located in a moderate relief valley setting with narrow, irregular overbank areas and steep valley walls on both sides.

Geomorphic conditions at bridge site: downstream (DS), upstream (US)

Date of inspection $\quad 9 / 3 / 96$

DS left: $\quad$ Mild sloping channel bank to a narrow overbank.

DS right: Mildly sloping channel bank to a narrow overbank.

US left: $\quad$ Moderately sloping channel bank to a narrow overbank.

US right: Steep channel bank to a narrow terrace.

\section{Description of the Channel}

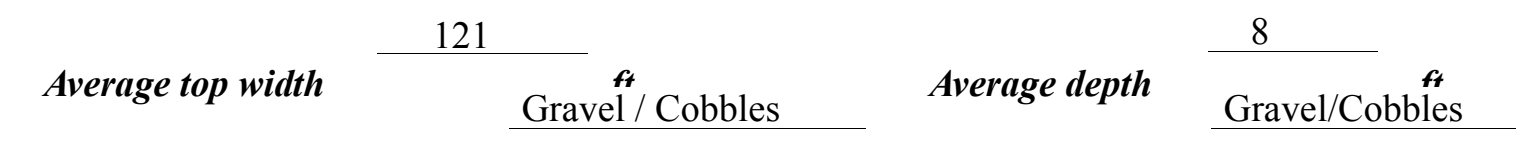

Predominant bed material

Bank material

Sinuous and laterally

unstable with wide point bars and semi-alluvial channel boundäries"

$9 / 3 / 96$

Vegetative col 1 Trees and brush

DS left: $\quad$ Trees, shrubs, and brush

DS right: $\quad$ Trees and brush

US left: $\quad$ Trees and shrubs

US right:

No

Do banks appear stable? The assessment on 9/3/96 indicated the reach was laterally unstable. A point bar adjacent to a cut-bank was noted in the upstream reach near the bridge. The bank
dite of observatton. material at the cut-bank was noted as slumped and the point bar width occupied about 60 percent of the channel width on the right side.

\section{A large deltaic}

accumulation of material was noted on 9/3/96. It is located on the left bank side of the channel at Describe any obstructions in channel and date of observation.

the downstream face of the bridge where a small tributary stream enters the Saxtons River. The accumulation blocks flows up to three feet in the left span. 


\section{Hydrology}

Drainage area $\quad 68.3 \boldsymbol{m i}^{2}$

Percentage of drainage area in physiographic provinces: (approximate)

Physiographic province/section New England / New England Upland
Percent of drainage area 100

Is drainage area considered rural or urban? — Rural _ Describe any significant urbanization:

Yes

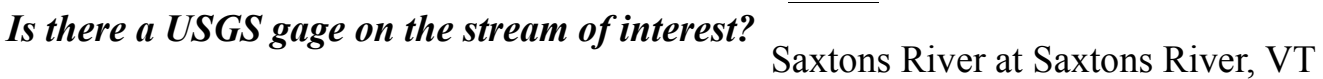
USGS gage description 01154000 (Discontinued, 1982)

USGS gage number 72.2

Gage drainage area $\quad \mathrm{mi}^{2}$ No

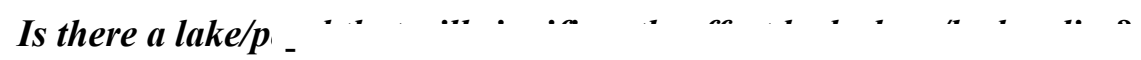

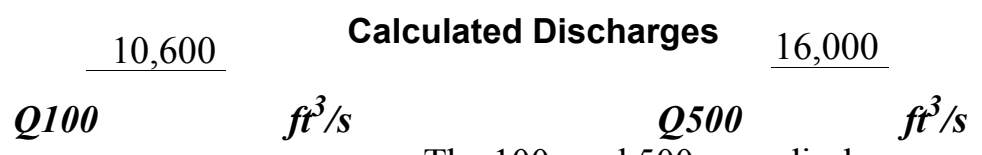

The 100- and 500-year discharges were taken from

the flood insurance study for the town of Rockingham (Federal Emergency Management Agency, 1979). These discharges were based on the period of gaged streamflow records from 1940 through 1982. 


\section{Description of the Water-Surface Profile Model (WSPRO) Analysis}

Datum for WSPRO analysis (USGS survey, sea level, VTAOT plans)

USGS survey

Datum tie between USGS survey and VTAOT plans

Subtract 23.9 feet from the USGS

arbitrary survey datum to obtain the VTAOT plans' datum.

Description of reference marks used to determine USGS datum. $\quad$ RM1 is the center point

of a chiseled "X" on top of the left abutment concrete at the downstream end (elev. 520.43 feet, arbitrary survey datum). RM2 is the center point of a chiseled " $\mathrm{X}$ " on top of the 10th concrete

guardrail post from the left end of the bridge on the downstream side (elev. 523.14 feet, arbitrary survey datum).

\section{Cross-Sections Used in WSPRO Analysis}

\begin{tabular}{ccll}
\hline${ }^{1}$ Cross-section & $\begin{array}{c}\text { Section } \\
\text { Reference } \\
\text { Distance } \\
\text { (SRD) in feet }\end{array}$ & $\begin{array}{c}{ }^{2} \text { Cross-section } \\
\text { development }\end{array}$ & \multicolumn{1}{c}{ Comments } \\
\hline EXITX & -170 & 1 & Exit section \\
FULLV & 0 & 2 & $\begin{array}{l}\text { Downstream Full-valley } \\
\text { section (Templated from } \\
\text { EXITX) }\end{array}$ \\
BRIDG & 0 & 1 & $\begin{array}{l}\text { Bridge section } \\
\text { Road Grade section }\end{array}$ \\
RDWAY & 26 & 1 & $\begin{array}{l}\text { Modelled Approach } \\
\text { section (Templated from } \\
\text { APTEM) }\end{array}$ \\
APTEM & 204 & 2 & $\begin{array}{l}\text { Approach section as } \\
\text { surveyed (Used as a } \\
\text { template) }\end{array}$ \\
\hline
\end{tabular}

${ }^{1}$ For location of cross-sections see plan-view sketch included with Level I field form, Appendix E. For more detail on how cross-sections were developed see WSPRO input file. 


\section{Data and Assumptions Used in WSPRO Model}

Hydraulic analyses of the reach were done by use of the Federal Highway Administration's WSPRO step-backwater computer program (Shearman and others, 1986, and Shearman, 1990). The analyses reported herein reflect conditions existing at the site at the time of the study. Furthermore, in the development of the model it was necessary to assume no accumulation of debris or ice at the site. Results of the hydraulic model are presented in the Bridge Hydraulic Summary, Appendix B, and figure 7.

Channel roughness factors (Manning's " $n$ ") used in the hydraulic model were estimated using field inspections at each cross section following the general guidelines described by Arcement and Schneider (1989). Final adjustments to the values were made during the modelling of the reach. Channel " $n$ " values for the reach ranged from 0.040 to 0.055 , and overbank " $n$ " values ranged from 0.050 to 0.060 .

Normal depth at the exit section (EXITX) was assumed as the starting water surface. This depth was computed by use of the slope-conveyance method outlined in the user's manual for WSPRO (Shearman, 1990). The slope used was $0.0053 \mathrm{ft} / \mathrm{ft}$, which was estimated from the 100-year-discharge water surface profile downstream of the site presented in the flood insurance study for the town of Rockingham (FEMA, 1979).

The surveyed approach section (APTEM) was moved along the approach channel slope $(0.0022 \mathrm{ft} / \mathrm{ft})$ to establish the modelled approach section (APPRO), one bridge length upstream

of the upstream face as recommended by Shearman and others (1986). This location also provides a consistent method for determining scour variables. 


\section{Bridge Hydraulics Summary}

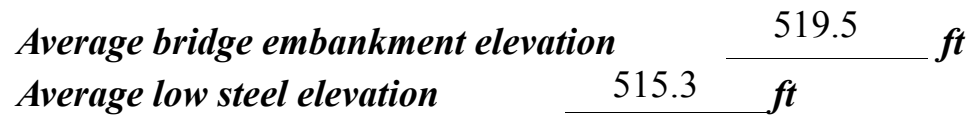

$$
\text { 100-year discharge } \quad 10,600 \quad \mathrm{ft}^{3} / \mathrm{s}
$$

Water-surface elevation in bridge opening $\quad 502.5 \quad f t$

Road overtopping? ___ No Discharge over road ___-- $\mathrm{ft}^{3} / \mathrm{s}$

\begin{tabular}{llcl} 
Area of flow in bridge opening & $1200 \quad \boldsymbol{f t}^{2}$ & \\
\cline { 2 - 3 } Average velocity in bridge opening & 8.8 & $\boldsymbol{f t} / \mathrm{s}$
\end{tabular}

Maximum WSPRO tube velocity at bridge $10.2 \mathrm{ft} / \mathrm{s}$

Water-surface elevation at Approach section with bridge 503.8

Water-surface elevation at Approach section without bridge

Amount of backwater caused by bridge

0.1 it

\section{7}

500-year discharge $\quad 16,000 \quad \mathrm{ft}^{3} / \mathrm{s}$

Water-surface elevation in bridge opening

$504.3 \mathrm{ft}$

Road overtopping? ___ No Discharge over road ___-- $f t^{3} / \mathrm{s}$

Area of flow in bridge opening $\quad 1420 \quad \mathrm{ft}^{2}$

Average velocity in bridge opening $11.3 \mathrm{ft} / \mathrm{s}$

Maximum WSPRO tube velocity at bridge 13.2 's

Water-surface elevation at Approach section with bridge

Water-surface elevation at Approach section without bridge

Amount of backwater caused by bridge

0.2

Incipient overtopping discharge ___ -- $\mathrm{ft}^{3} / \mathrm{s}$

Water-surface elevation in bridge opening $\quad-t_{t}$

Area of flow in bridge opening _ _- $\mathrm{ft}^{2}$

Average velocity in bridge opening $\quad--\quad \mathrm{ft} / \mathrm{s}$

Maximum WSPRO tube velocity at bridge _-- $f t / s$

Water-surface elevation at Approach section with bridge

Water-surface elevation at Approach section without bridge

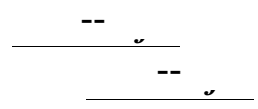
Amount of backwater caused by bridge _ 


\section{Scour Analysis Summary}

\section{Special Conditions or Assumptions Made in Scour Analysis}

Scour depths were computed using the general guidelines described in Hydraulic Engineering Circular 18 (Richardson and others, 1995). Scour depths were calculated assuming an infinite depth of erosive material and a homogeneous particle-size distribution. The results of the scour analysis are presented in tables 1 and 2 and a graph of the scour depths is presented in figure 8 .

Contraction scour was computed by use of the clear-water contraction scour equation (Richardson and others, 1995, p. 32, equation 20). For contraction scour computations, the average depth in the contracted section (AREA/TOPWIDTH) is subtracted from the depth of flow computed by the scour equation (Y2) to determine the actual amount of scour.

Abutment scour was computed by use of the Froehlich equation (Richardson and others, 1995, p. 48, equation 28). Variables for the Froehlich equation include the Froude number of the flow approaching the embankments, the length of the embankment blocking flow, and the depth of flow approaching the embankment less any roadway overtopping.

Because the influence of scour processes on the spill-through embankment material is uncertain, the scour depth at the vertical concrete abutment walls is unknown. Therefore, scour depths were applied for the entire spill-through embankment area below the elevation at the toe of each embankment, as shown in figure 8.

Pier scour was computed by use of an equation developed at Colorado State University (Richardson and others, 1995, p. 36, equation 21) for all discharges modeled. Variables for the pier scour equation include pier length, pier width, average depth and maximum velocity (for the froude number) immediately upstream of the bridge, and correction factors for pier shape, flow attack angle, streambed-form, and streambed armoring. 


\section{Scour Results}
100-yr discharge 500-yr discharge
Incipient
overtopping
(Scour depths in feet)

Contraction scour:

Main channel
Live-bed scour
Clear-water scour
Depth to armoring

Left overbank

Right overbank

Local scour:

Abutment scour
\[ \begin{array}{l}\text { Left abutment } \\ \text { Right abutment }\end{array} \]

Pier scour

Pier 1

Pier 2

Pier 3
Abutments:

Left abutment

Right abutment

Piers:

Pier 1

Pier 2
9.0

9.1-

9.0

13.7
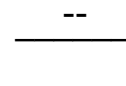

13.4

11.7-

12.1

18.4

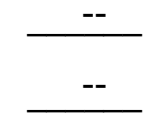

\section{Riprap Sizing}

Incipient overtopping 100-yr discharge 500-yrdischarge discharge

1.5

1.5

$1.4^{-}$

1.4

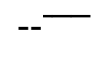

( $D_{50}$ in feet)

2.4 --

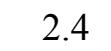

$2.3^{-}$

2.3

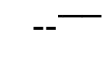

$--$ 


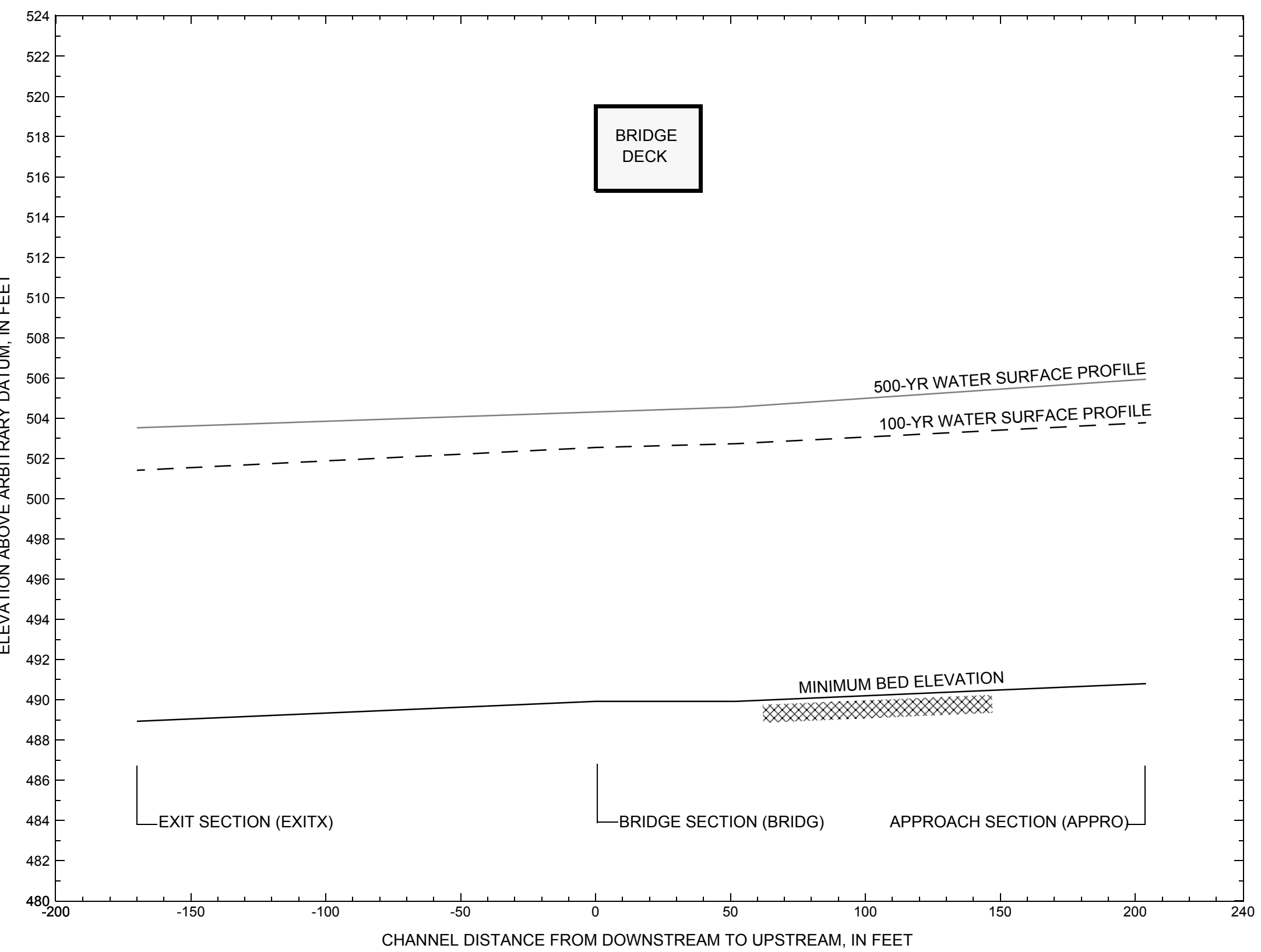

Figure 7. Water-surface profiles for the 100- and 500-yr discharges at structure ROCKTH0001011R on Town Highway 1, crossing the Saxtons River, Rockingham, Vermont. 


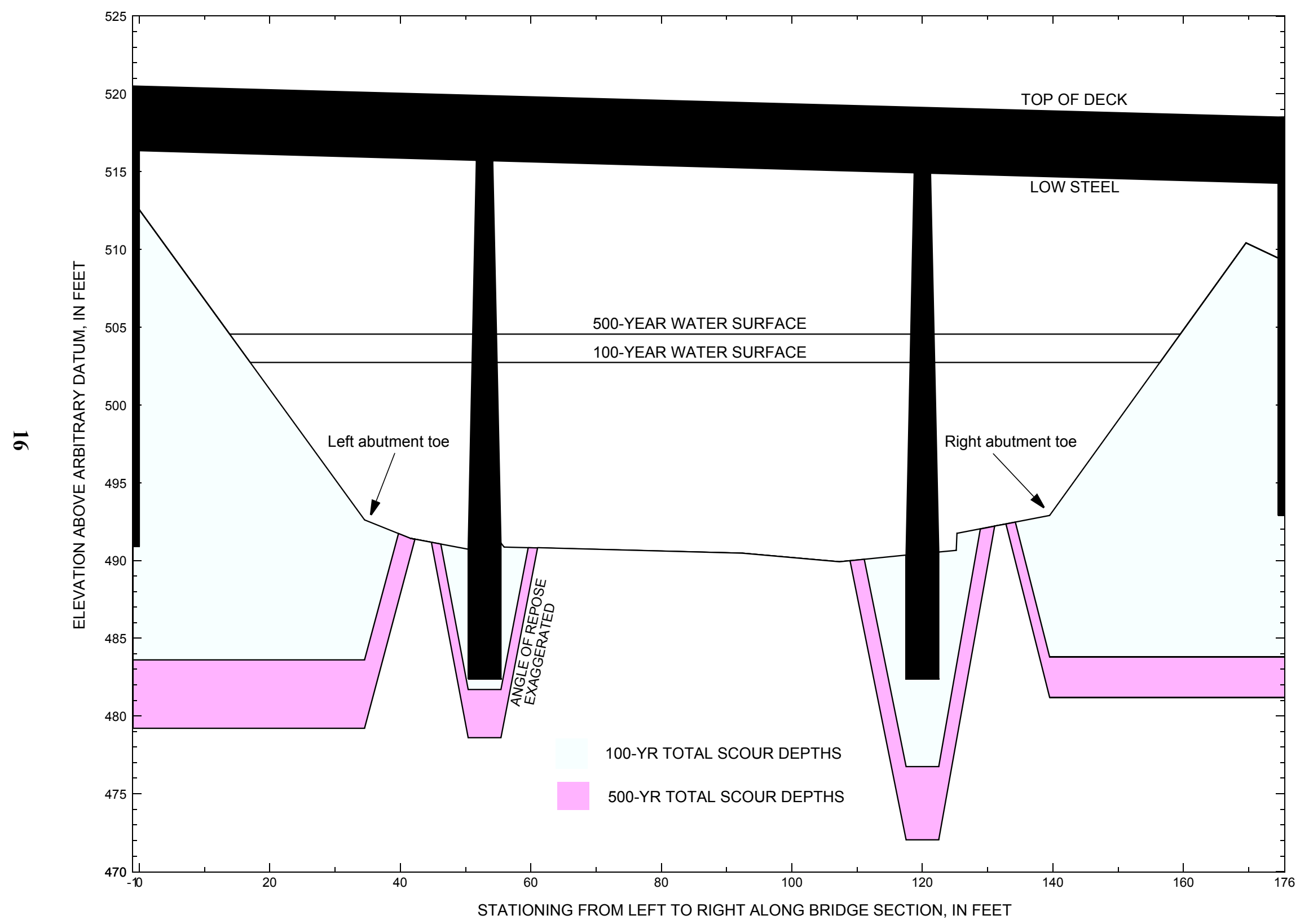

Figure 8. Scour elevations for the 100-yr and 500-yr discharges at structure ROCKTH0001011R on Town Highway 1, crossing the Saxtons River, Rockingham, Vermont. 


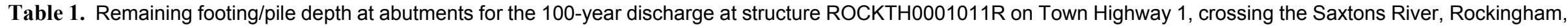
Vermont.

[VTAOT, Vermont Agency of Transportation; --,no data]

\begin{tabular}{|c|c|c|c|c|c|c|c|c|c|c|c|}
\hline Description & Station $^{1}$ & $\begin{array}{c}\text { VTAOT } \\
\text { Bridge seat } \\
\text { elevation } \\
\text { (feet) }\end{array}$ & $\begin{array}{l}\text { Surveyed } \\
\text { minimum } \\
\text { low-chord } \\
\text { elevation }{ }^{2} \\
\text { (feet) }\end{array}$ & $\begin{array}{c}\text { Bottom of } \\
\text { footing } \\
\text { elevation } \\
\text { (feet) }\end{array}$ & $\begin{array}{c}\text { Channel } \\
\text { elevation at } \\
\text { abutment/ } \\
\text { pier }^{2} \\
\text { (feet) }\end{array}$ & $\begin{array}{l}\text { Contraction } \\
\text { scour depth } \\
\text { (feet) }\end{array}$ & $\begin{array}{l}\text { Abutment } \\
\text { scour } \\
\text { depth } \\
\text { (feet) }\end{array}$ & $\begin{array}{l}\text { Pier } \\
\text { scour } \\
\text { depth } \\
\text { (feet) }\end{array}$ & $\begin{array}{l}\text { Depth of } \\
\text { total scour } \\
\text { (feet) }\end{array}$ & $\begin{array}{c}\text { Elevation of } \\
\text { scour }^{2} \\
\text { (feet) }\end{array}$ & $\begin{array}{c}\text { Remaining } \\
\text { footing/pile } \\
\text { depth } \\
\text { (feet) }\end{array}$ \\
\hline \multicolumn{12}{|c|}{100 -yr. discharge is 10,600 cubic-feet per second } \\
\hline Left abutment & 0.0 & 491.3 & 516.4 & 490.9 & 512.6 & -- & -- & -- & -- & -- & -7.3 \\
\hline Left abutment toe & 34.5 & -- & -- & -- & 492.6 & 0.0 & 9.0 & -- & 9.0 & 483.6 & -- \\
\hline Pier 1 & 52.9 & 490.6 & -- & 482.4 & 490.7 & 0.0 & -- & 9.0 & 9.0 & 481.7 & -0.7 \\
\hline Pier 2 & 120.0 & 489.8 & -- & 482.4 & 490.4 & 0.0 & -- & 13.7 & 13.7 & 476.7 & -5.7 \\
\hline Right abutment toe & 139.5 & -- & -- & -- & 492.9 & 0.0 & 9.1 & -- & 9.1 & 483.8 & -- \\
\hline Right abutment & 174.5 & 489.2 & 514.3 & 492.9 & 509.4 & -- & -- & -- & -- & -- & -9.1 \\
\hline
\end{tabular}

1.Measured along the face of the most constricting side of the bridge

2.Arbitrary datum for this study.

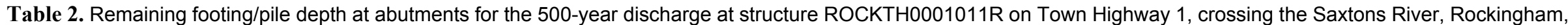
Vermont.

[VTAOT, Vermont Agency of Transportation; --, no data]

\begin{tabular}{|c|c|c|c|c|c|c|c|c|c|c|c|}
\hline Description & Station ${ }^{1}$ & $\begin{array}{c}\text { VTAOT } \\
\text { Bridge seat } \\
\text { elevation } \\
\text { (feet) }\end{array}$ & $\begin{array}{l}\text { Surveyed } \\
\text { minimum } \\
\text { low-chord } \\
\text { elevation }{ }^{2} \\
\text { (feet) }\end{array}$ & $\begin{array}{c}\text { Bottom of } \\
\text { footing } \\
\text { elevation } \\
\text { (feet) }\end{array}$ & $\begin{array}{c}\text { Channel } \\
\text { elevation at } \\
\text { abutment/ } \\
\text { pier }^{2} \\
\text { (feet) }\end{array}$ & $\begin{array}{c}\text { Contraction } \\
\text { scour depth } \\
\text { (feet) }\end{array}$ & $\begin{array}{l}\text { Abutment } \\
\text { scour } \\
\text { depth } \\
\text { (feet) }\end{array}$ & $\begin{array}{l}\text { Pier } \\
\text { scour } \\
\text { depth } \\
\text { (feet) }\end{array}$ & $\begin{array}{l}\text { Depth of } \\
\text { total scour } \\
\text { (feet) }\end{array}$ & $\begin{array}{c}\text { Elevation of } \\
\text { scour }^{2} \\
\text { (feet) }\end{array}$ & $\begin{array}{c}\text { Remaining } \\
\text { footing/pile } \\
\text { depth } \\
\text { (feet) }\end{array}$ \\
\hline \multicolumn{12}{|c|}{500 -yr. discharge is 16,000 cubic-feet per second } \\
\hline Left abutment & 0.0 & 491.3 & 516.4 & 490.9 & 512.6 & -- & -- & -- & -- & -- & -11.7 \\
\hline Left abutment toe & 34.5 & -- & -- & -- & 492.6 & 0.0 & 13.4 & -- & 13.4 & 479.2 & -- \\
\hline Pier 1 & 52.9 & 490.6 & -- & 482.4 & 490.7 & 0.0 & -- & 12.1 & 12.1 & 478.6 & -3.8 \\
\hline Pier 2 & 120.0 & 489.8 & -- & 482.4 & 490.4 & 0.0 & -- & 18.4 & 18.4 & 472.0 & -10.4 \\
\hline Right abutment toe & 139.5 & -- & -- & -- & 492.9 & 0.0 & 11.7 & -- & 11.7 & 481.2 & -- \\
\hline Right abutment & 174.5 & 489.2 & 514.3 & 492.9 & 509.4 & -- & -- & -- & -- & -- & -11.7 \\
\hline
\end{tabular}

1.Measured along the face of the most constricting side of the bridge

2.Arbitrary datum for this study. 


\section{SELECTED REFERENCES}

Arcement, G.J., Jr., and Schneider, V.R., 1989, Guide for selecting Manning's roughness coefficients for natural channels and flood plains: U.S. Geological Survey Water-Supply Paper 2339, 38 p.

Barnes, H.H., Jr., 1967, Roughness characteristics of natural channels: U.S. Geological Survey Water-Supply Paper 1849,213 p.

Benson, M. A., 1962, Factors Influencing the Occurrence of Floods in a Humid Region of Diverse Terrain: U.S. Geological Survey WaterSupply Paper 1580-B, 64 p.

Brown, S.A. and Clyde, E.S., 1989, Design of riprap revetment: Federal Highway Administration Hydraulic Engineering Circular No. 11, Publication FHWA-IP-89-016, 156 p.

Federal Highway Administration, 1983, Runoff estimates for small watersheds and development of sound design: Federal Highway Administration Report FHWA-RD-77-158

Federal Emergency Management Agency, 1979, Flood Insurance Study, Town of Rockingham and Village of Bellows Falls, Windham County, Vermont: Washington, D.C., November 1979.

Froehlich, D.C., 1989, Local scour at bridge abutments in Ports, M.A., ed., Hydraulic Engineering--Proceedings of the 1989 National Conference on Hydraulic Engineering: New York, American Society of Civil Engineers, p. 13-18.

Hayes, D.C.,1993, Site selection and collection of bridge-scour data in Delaware, Maryland, and Virginia: U.S. Geological Survey WaterResources Investigation Report 93-4017, 23 p.

Interagency Advisory Committee on Water Data, 1982, Guidelines for determining flood flow frequency: U.S. Geological Survey, Bulletin 17B of the Hydrology Subcommittee, 190 p.

Johnson, C.G. and Tasker, G.D.,1974, Progress report on flood magnitude and frequency of Vermont streams: U.S. Geological Survey OpenFile Report 74-130, 37 p.

Lagasse, P.F., Schall, J.D., Johnson, F., Richardson, E.V., Chang, F., 1995, Stream Stability at Highway Structures: Federal Highway Administration Hydraulic Engineering Circular No. 20, Publication FHWA-IP-90-014, 144 p.

Laursen, E.M., 1960, Scour at bridge crossings: Journal of the Hydraulics Division, American Society of Civil Engineers, v. 86, no. HY2, p. 39-53.

Potter, W. D., 1957a, Peak rates of runoff in the Adirondack, White Mountains, and Maine woods area, Bureau of Public Roads

Potter, W. D., 1957b, Peak rates of runoff in the New England Hill and Lowland area, Bureau of Public Roads

Richardson, E.V. and Davis, S.R., 1995, Evaluating scour at bridges: Federal Highway Administration Hydraulic Engineering Circular No. 18, Publication FHWA-IP-90-017, 204 p.

Richardson, E.V., Simons, D.B., and Julien, P.Y., 1990, Highways in the river environment: Federal Highway Administration Publication FHWA-HI-90-016.

Ritter, D.F., 1984, Process Geomorphology: W.C. Brown Co., Debuque, Iowa, 603 p.

Shearman, J.O., 1990, User's manual for WSPRO--a computer model for water surface profile computations: Federal Highway Administration Publication FHWA-IP-89-027, 187 p.

Shearman, J.O., Kirby, W.H., Schneider, V.R., and Flippo, H.N., 1986, Bridge waterways analysis model; research report: Federal Highway Administration Publication FHWA-RD-86-108, 112 p.

Talbot, A.N., 1887, The determination of water-way for bridges and culverts.

U.S. Department of Transportation, 1993, Stream stability and scour at highway bridges, Participant Workbook: Federal Highway Administration Publication FHWA HI-91-011.

U.S. Geological Survey, 1985, Bellows Falls, Vermont 7.5 by 15 Minute Series quadrangle map: U.S. Geological Survey Topographic Maps, Aerial photographs, 1977; Contour interval , 6 meters; Scale 1:25,000

U.S. Geological Survey, 1984, Saxtons River, Vermont 7.5 by 15 Minute Series quadrangle map: U.S. Geological Survey Topographic Maps, Aerial photographs, 1977; Contour interval, 6 meters, Scale 1:25,000. 


\section{APPENDIX A: \\ WSPRO INPUT FILE}




\section{WSPRO INPUT FILE}

XS

GR

GR

GR

GR

*

$\mathrm{N}$

SA

\section{*}

XS

*

*

$\mathrm{BR}$

GR

GR

GR

GR

*

XR

GR

GR

*

$\mathrm{XT}$

GR

GR

GR

GR

GR

AS

GT

$\mathrm{N}$

SA
U.S. Geological Survey WSPRO Input File rock11r.wsp Hydraulic analysis for structure ROCKTH0001011R Date: 31-JAN-97 Town Highway 1 (VT 121 \& FAS 125) over Saxtons River, Rockingham EMB

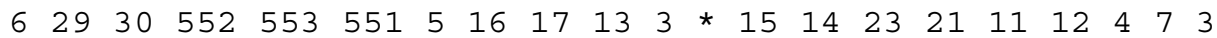

$10600.0 \quad 16000.0$

$0.0053 \quad 0.0053$

EXITX -170

$-99.1,511.76$

$62.0,490.18$

$-59.1,501.45$

$20.0,499.57$

$44.8,492.20$

$82.8,489.63$

$94.4,488.93$

$110.4,489.69$

$112.6,490.23$

$142.9,499.00$

$163.9,501.64$

$324.9,506.18$

$370.2,515.62$

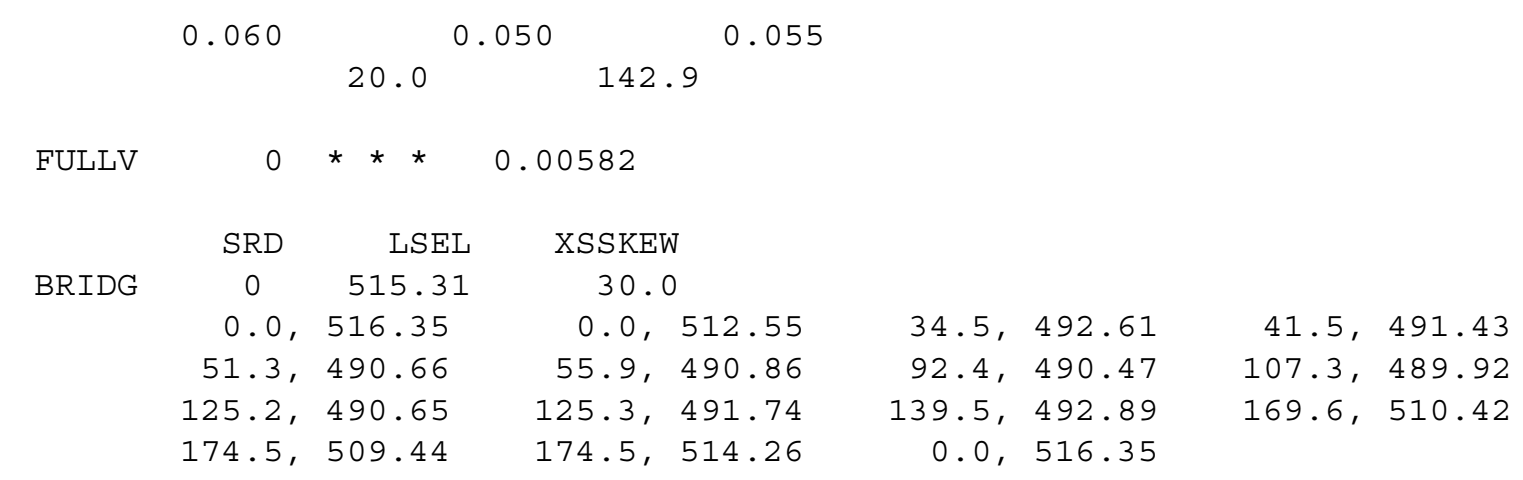

Scour hole removed as it is not present at upstream face...

$118.2,487.48 \quad 122.8,488.36 \quad 52.9,514.37 \quad 120.0,513.64$

BRTYPE BRWDTH EMBSS EMBELV

$\begin{array}{llll}3 & 52.6 & 1.0 & 519.5\end{array}$

$489.92,10.0 \quad 514.91,5.0 \quad 514.91,2.5 \quad 515.72,2.5$

$515.72, \quad 0.0$

0.040

SRD EMBWID IPAVE

RDWAY $26 \quad 39.0 \quad 1$

$\begin{array}{lllll}-172.8,523.63 & -135.5,522.25 & -11.0,520.07 & 0.0,520.49\end{array}$

$174.2,518.51$

APTEM 231

$-45.1,517.18$

$-12.6,503.03$

$20.0,502.42$

$30.6,499.28$

$45.3,492.80$

$51.7,492.11$

$53.3,491.31$

$59.2,491.14$

$67.6,490.99$

$71.3,490.86$

$78.0,491.25$

$84.9,492.07$

$109.1,495.13$

$132.3,496.84$

$138.8,502.10$

$156.0,501.38$

$166.7,509.50$

$205.2,513.84$

$263.9,514.96$

APPRO

$$
204 * * * 0.0022
$$

0.050

0.055

20.0

HP 1 BRIDG 502.541502 .54

HP 2 BRIDG 502.54 * * 10600

HP 2 BRIDG 502.73* * 10600

$\mathrm{HP} 1 \mathrm{APPRO} 503.771503 .77$

$\mathrm{HP} 2$ APPRO 503.77 * * 10600 


\section{APPENDIX B: \\ WSPRO OUTPUT FILE}


WSPRO OUTPUT FILE

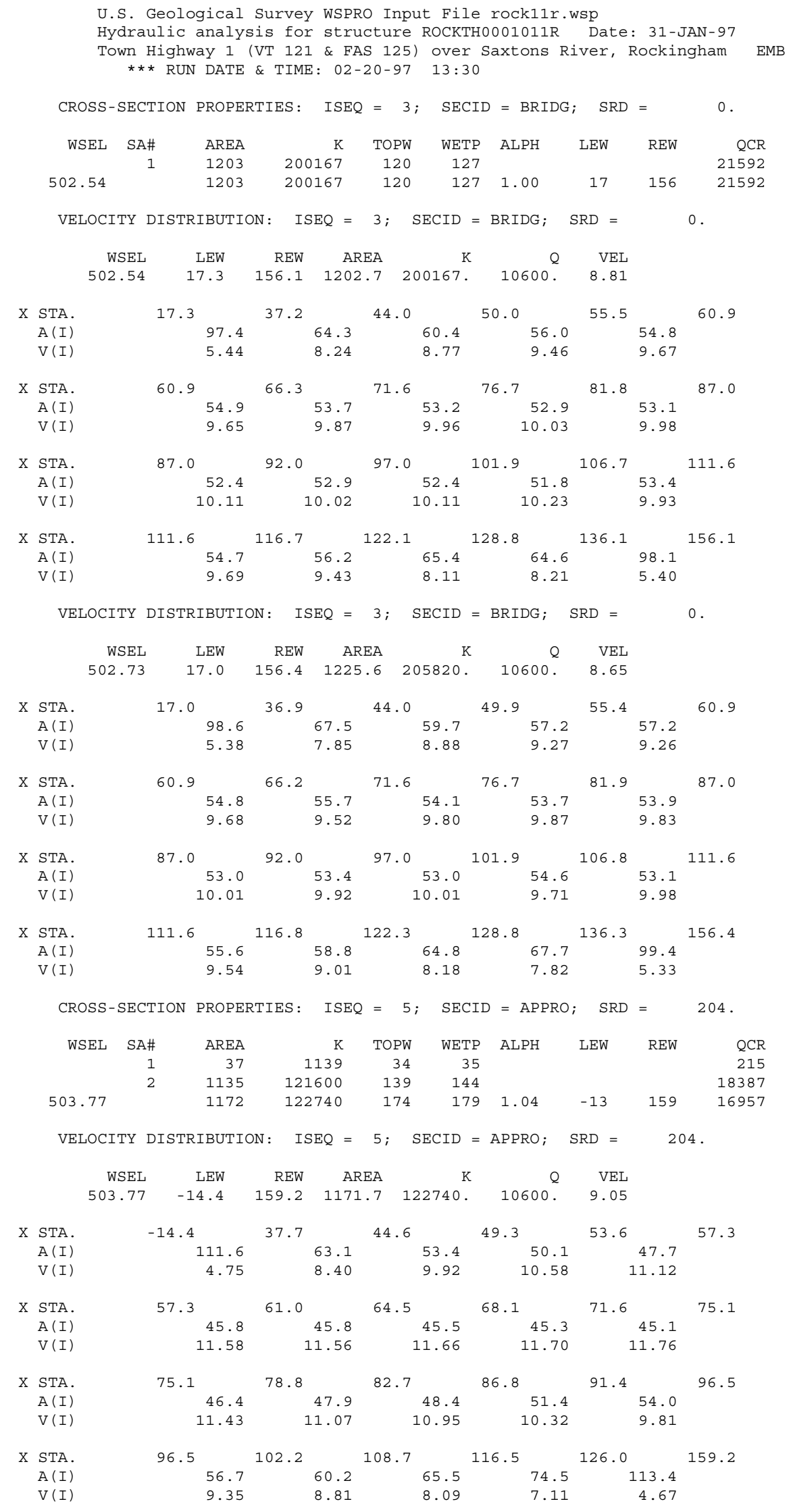


WSPRO OUTPUT FILE (continued)

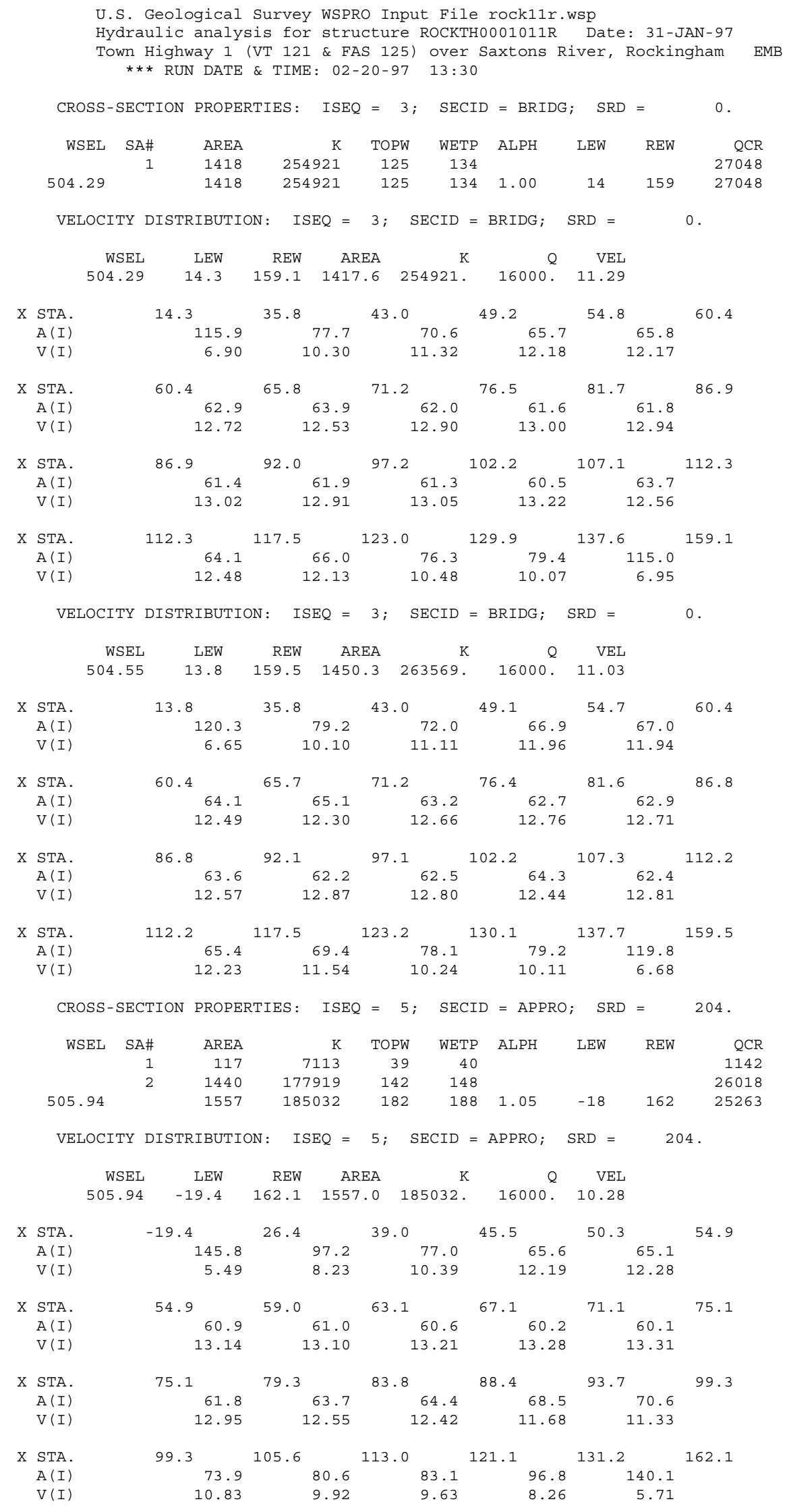


WSPRO OUTPUT FILE (continued)

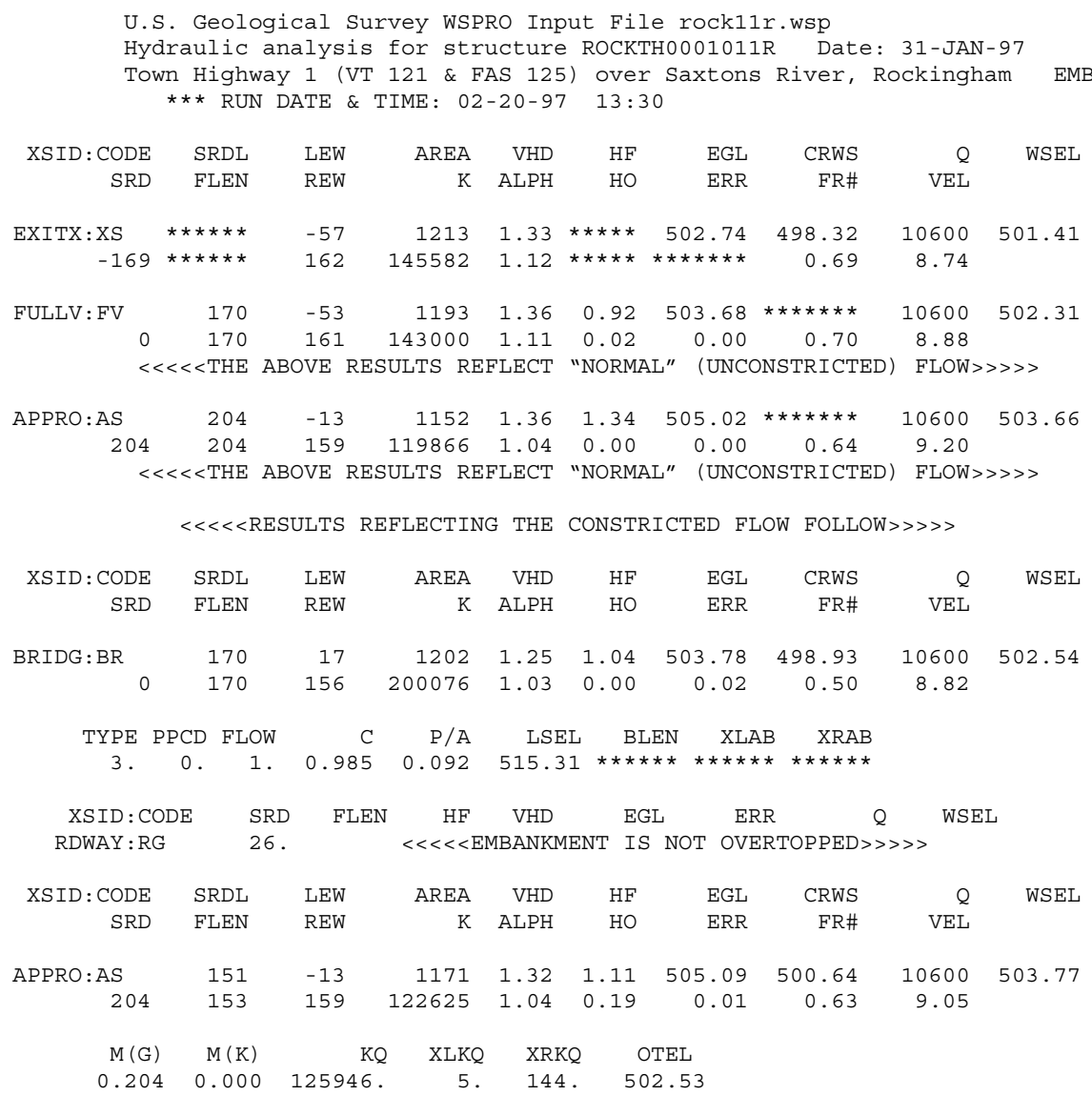

$<<<<$ END OF BRIDGE COMPUTATIONS $>>>>>$

FIRST USER DEFINED TABLE.

\begin{tabular}{|c|c|c|c|c|c|c|c|c|}
\hline XSID : CODE & SRD & LEW & REW & $Q$ & K & AREA & VEL & WSEL \\
\hline EXITX:XS & -170. & -58 & 162. & 10600 . & 145582. & 1213. & 8.74 & 501.41 \\
\hline FULLV : FV & 0 . & -54 & 161. & 10600 . & 143000 . & 1193. & 8.88 & 502.31 \\
\hline BRIDG : BR & 0 . & 17. & 156. & 10600 . & 200076 . & 1202. & 8.82 & 502.54 \\
\hline RDWAY : RG & \multicolumn{3}{|c|}{$26 . * \star \star * * * \star * * * * \star * \star * *$} & \multicolumn{3}{|c|}{$0 . * * * * * * * \star * * \star * * * * * * * * *$} & \multicolumn{2}{|c|}{ 1. $00 * \star \star \star * \star * * *$} \\
\hline APPRO : AS & 204. & -14 & 159. & 10600 . & 122625 . & 1171. & 9.05 & 503.77 \\
\hline XSID : CODE & XLKQ & XRKQ & & & & & & \\
\hline APPRO: AS & 5. & 144. & 12594 & & & & & \\
\hline
\end{tabular}

SECOND USER DEFINED TABLE.

\begin{tabular}{|c|c|c|c|c|c|c|c|c|c|}
\hline XSID : CODI & CRWS & FR\# & YMIN & YMAX & $\mathrm{HF}$ & $\mathrm{HO}$ & VHD & EGL & WSEL \\
\hline EXITX:XS & 498.32 & .69 & 488.93 & $515.62^{*}$ & 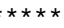 & *** & 1.33 & 502.74 & 501.41 \\
\hline ULLV : FV & 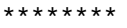 & 70 & 489.92 & 516.61 & 0.92 & 0.02 & 1.36 & 03.68 & 502.31 \\
\hline BRIDG : BR & 498.93 & .50 & 489.92 & 516.35 & 1.04 & 0.00 & 1.25 & 503.78 & 502.54 \\
\hline RDWA : RG & $\star \star \star \star \star \star * \star * *$ & $\star \star \star * *$ & 518.51 & $523.63 *$ & $* * * *$ & $\star * *$ & $\star \star * *$ & $\star * *$ & $\star \star \star \star * \star *$ \\
\hline PPRO : AS & 500.64 & 0.63 & 490.80 & 517.12 & 1.11 & 0.19 & 1.32 & 505.09 & 503.77 \\
\hline
\end{tabular}


WSPRO OUTPUT FILE (continued)

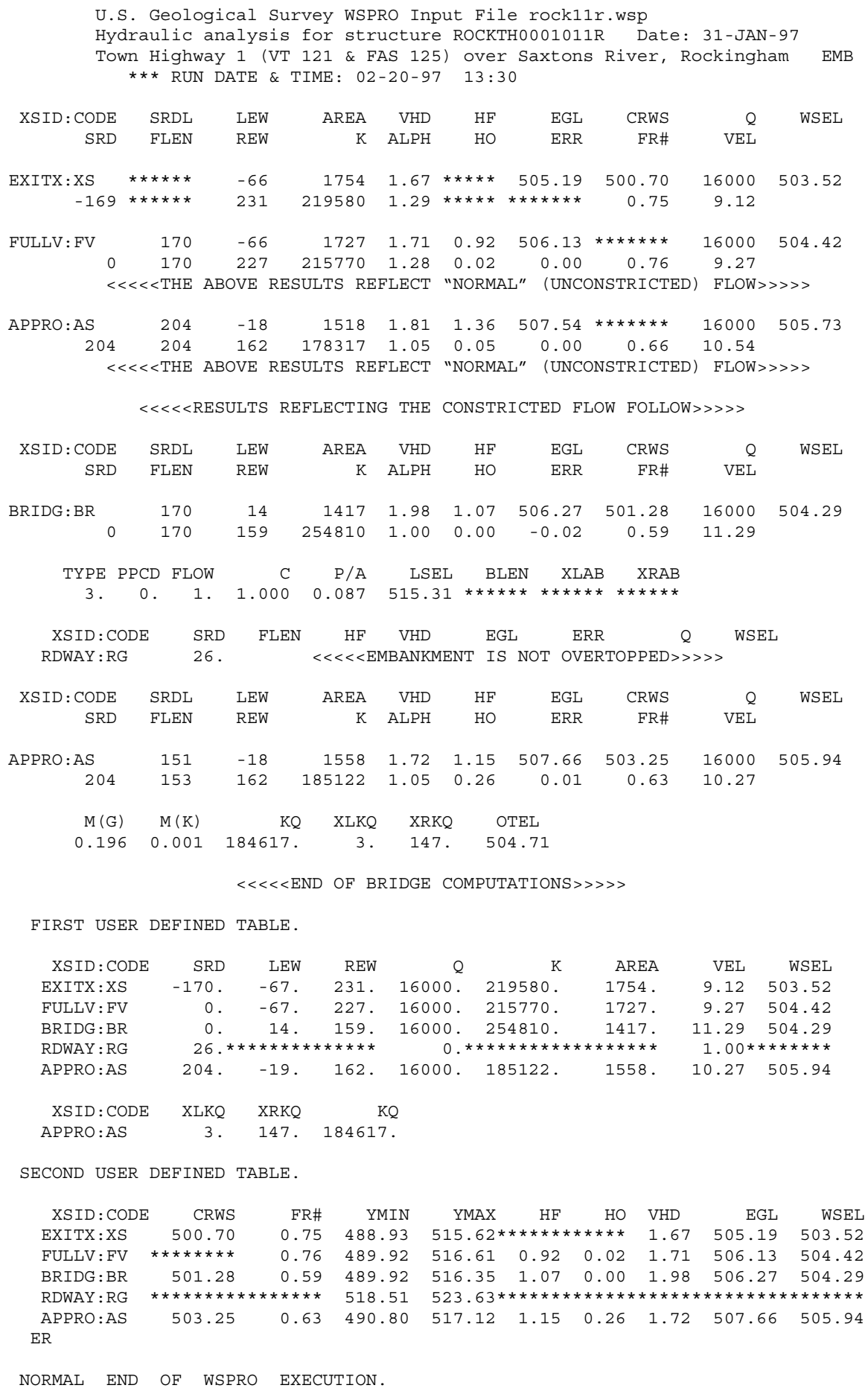




\section{APPENDIX C:}

\section{BED-MATERIAL PARTICAL-SIZE DISTRIBUTION}




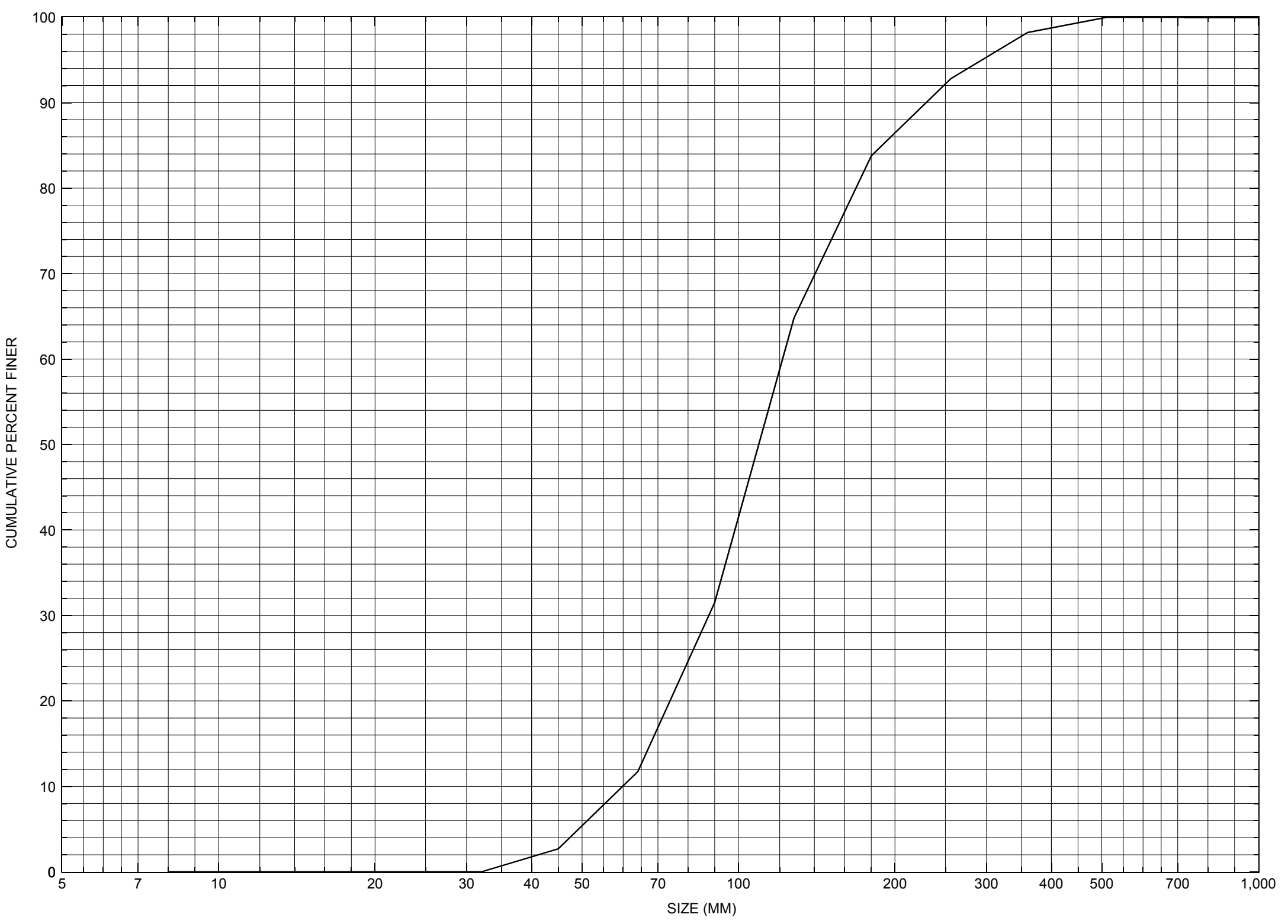

Appendix C. Bed material particle-size distribution for a pebble count in the channel approach of structure ROCKTH0001011R, in Rockingham, Vermont. 


\section{APPENDIX D: \\ HISTORICAL DATA FORM}




\section{Structure Number ROCKTH0001011R}

\section{General Location Descriptive}

Data collected by (First Initial, Full last name) $\mathbf{E}$. BOEHMLER

Date $(M M / D D / Y Y) \_\mathbf{0 3} / \underline{\mathbf{3 0} /} \mathbf{9 5}$

Highway District Number $(I-2 ; n n) \underline{\mathbf{0 2}}$

Town (FIPS place code; I - 4; nnnnn) $\mathbf{6 0 2 5 0}$

Waterway (I - 6) SAXTONS RIVER

Route Number TH001

Topographic Map Saxtons.River

Latitude (I - 16; nnnn.n) $\mathbf{4 3 0 8 4}$
County (FIPS county code; I - 3; nnn)

Mile marker (I - 11; nnn.nnn) $\mathbf{0 0 3 3 6 0}$

Road Name (I - 7): -

Vicinity (I - 9) 4.1 MI W JCT. U.S.5

Hydrologic Unit Code: $\underline{\mathbf{0 1 0 8 0 1 0 7}}$

Longitude (i - 17; nnnnn.n) $\mathbf{7 2 3 0 1}$

\section{Select Federal Inventory Codes}

FHWA Structure Number (I - 8) _ 200126011R1314

Maintenance responsibility $(I-21 ; n n) \quad \mathbf{0 3}$

Year built (I - 27; YYYY) 1954

Average daily traffic, ADT (I - 29; nnnnnn) 002480

Year of ADT (I - 30; YY) $\mathbf{9 1}$

Opening skew to Roadway $(I-34 ; n n) \quad 30$

Operational status $(I-41 ; X) \quad \mathbf{A}$

Structure type (I - 43; nnn) $\mathbf{4 0 2}$

Approach span structure type (I - 44; nnn) $\mathbf{0 0 0}$

Number of spans (I - 45; nnn) $\underline{\mathbf{0 0 3}}$

Number of approach spans (I - 46; nnnn) $\mathbf{0 0 0 0}$

Comments:

The structural inspection report of 8/10/94 indicates the structure is a three span, continuous steel stringer type bridge with a concrete deck and an asphalt roadway surface. The abutments are the concrete skeletal type, which reportedly have only minor cracks. The wingwalls are concrete, which is in good condition overall. The wingwalls are very short and only exposed at the very top where the flow through abutment embankments end at the wingwall and abutment concrete. Both piers are solid concrete, which have some minor cracks and scaling at the ends of each. The footings of the piers are not exposed. There is some local scour reported at the upstream end of the left pier. In the scour hole, (Continued, page 31) 


\section{Bridge Hydrologic Data}

Is there hydrologic data available? $\underline{\mathbf{N}}$ if No, type ctrl-n $h \quad$ VTAOT Drainage area $\left(m i^{2}\right)$ : -

Terrain character:

Stream character \& type: -

Streambed material:

Discharge Data (cfs):

$$
\begin{aligned}
& Q_{2.33}- \\
& Q_{50}-
\end{aligned}
$$

Record flood date $(M M / D D / Y Y)$ :

Estimated Discharge (cfs): Ice conditions (Heavy, Moderate, Light) : -

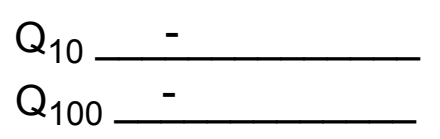

$$
\begin{aligned}
& Q_{25}- \\
& Q_{500}-
\end{aligned}
$$

Water surface elevation $(f t):-$

The stage increases to maximum highwater elevation (Rapidly, Not rapidly):

The stream response is (Flashy, Not flashy):

Describe any significant site conditions upstream or downstream that may influence the stream's stage: -

Watershed storage area (in percent): _ _ \%

The watershed storage area is: - (1-mainly at the headwaters; 2- uniformly distributed; 3-immediatly upstream oi the site)

Water Surface Elevation Estimates for Existing Structure:

\begin{tabular}{|l|l|l|l|l|l|}
\hline Peak discharge frequency & $Q_{2.33}$ & $Q_{10}$ & $Q_{25}$ & $Q_{50}$ & $Q_{100}$ \\
Water surface elevation (ft)) & - & - & - & - & - \\
Velocity (ft/sec) & - & - & - & - & - \\
\hline
\end{tabular}

Long term stream bed changes: -

Is the roadway overtopped below the $\mathrm{Q}_{100}$ ? (Yes, No, Unknown): $\mathbf{U}$ Frequency: Relief Elevation (ft): Discharge over roadway at $Q_{100}\left(f^{3} / \mathrm{sec}\right)$ :

Are there other structures nearby? (Yes, No, Unknown): $\underline{\mathbf{U}}$ Upstream distance (miles): Town: If No or Unknown, type ctrl-n os Highway No. : Structure No. : Year Built:

Clear span (ft): Clear Height $(f t)$ : Full Waterway $\left(f^{2}\right)$ : 
Downstream distance (miles): Town: Year Built:

Highway No. : Structure No. : Structure Type:

Clear span $(f t):$ Clear Height $(f t)$ : Full Waterway $\left(f^{2}\right)$ :

Comments:

there is heavy stone riprap reported. The waterway proceeds straight through the bridge. The streambed consists of stone and gravel. There is a shallow point bar reported in the right most span and part of the middle span. Debris accumulation is reported as minor at this site. The report indicates that bank erosion is not evident.

\section{USGS Watershed Data}

Watershed Hydrographic Data

Drainage area (DA) $\mathbf{6 8 . 2 7} \mathrm{mi}^{2}$ Lake and pond area $\mathrm{mi}^{2}$

Watershed storage (ST)

Bridge site elevation 433 0.5 $\%$

Main channel length 16.95 $\mathrm{ft}$ Headwater elevation 2894 $\mathrm{ft}$ $10 \%$ channel length elevation $\mathbf{5 1 2}$ $\mathrm{ft} \quad 85 \%$ channel length elevation 1693 $\mathrm{ft}$

Main channel slope (S) (S) 92.89 $\mathrm{ft} / \mathrm{mi}$

Watershed Precipitation Data

Average site precipitation in Average headwater precipitation in

Maximum 2yr-24hr precipitation event $(124,2)$ in

Average seasonal snowfall (Sn) $\mathrm{ft}$ 


\section{Bridge Plan Data}

Are plans available? $\underline{\mathbf{Y}}$ If no, type ctrl-n pl Date issued for construction (MM/YYYY): $\underline{\mathbf{0 8}}$ / 1953 Project Number $\mathbf{S}$ 156(3)

Minimum channel bed elevation: $\mathbf{4 6 6 . 0}$

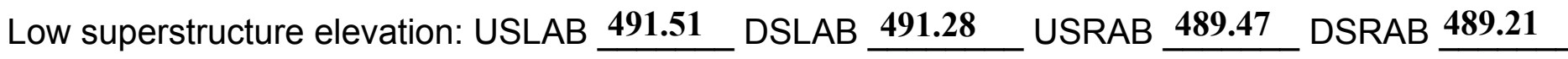

Benchmark location description:

BM\#1, chiseled square, located 147 feet from the center-line of the left abutment, and 17 feet left of the roadway center-line, elevation $\mathbf{5 0 0 . 0}$

Reference Point (MSL, Arbitrary, Other): Arbitrary $\quad$ Datum (NAD27, NAD83, Other): Arbitrary Foundation Type: 1 (1-Spreadfooting; 2-Pile; 3- Gravity; 4-Unknown)

If 1: Footing Thickness $\mathbf{2 . 5}$ Footing bottom elevation: $\underline{467.0 *}$

If 2: Pile Type: ___ (1-Wood; 2-Steel or metal; 3-Concrete) Approximate pile driven length:

If 3: Footing bottom elevation:

Is boring information available? $\underline{\mathbf{Y}}$ If no, type ctrl- $n$ bi Number of borings taken: $\underline{9}$

Foundation Material Type: 1 (1-regolith, 2-bedrock, 3-unknown)

Briefly describe material at foundation bottom elevation or around piles:

Borings surrounding the right abutment: B1 (downstream bankward corner) stone and boulder, B7 (center bankward) gravel with clay filler, B8 (downstream side of abutment) boulder and stone. Right pier: B2 (downstream bankward side) gravel with clay filler, B3 (upstream bankward side) gravel with clay filler (hard) at the footing depth. Left pier: B4 (upstream streamward side) gravel with clay filler, B5 (downstream streamward side) gravel with clay filler at the footing depth. Left abutment: B6 (streamward side) sharp medium sand small amount of fine gravel with clay filler.

\section{Comments:}

*The right and left pier footing base elevation is shown at an elevation of 458.5 with a 3 foot thickness. The left abutment footing base elevation is shown at 467.0 with a 2.5 foot thickness, set on a sharp medium sand with a small amount of fine gravel with clay filler. The right abutment footing base elevation is shown at 469.0, with a 2.5 foot thickness and set on a stone and boulder material. The low superstructure elevations of the piers: pier 1(left) upstream end 490.88 and downstream end 490.63; pier 2(right) upstream end 490.09 and downstream end 489.84 . 


\section{Cross-sectional Data}

Is cross-sectional data available? $\underline{\mathbf{Y}}$ If no, type ctrl-n xs

Source (FEMA, VTAOT, Other)? FEMA

Comments: The station and elevation measurements are in feet. The low cord to bed length measurements at the abutments differ from the $9 / 96$ survey.

\begin{tabular}{|l|l|l|l|l|l|l|l|l|l|l|l|}
\hline Station & 315 & 325 & 366 & 400 & 436 & 485 & 491 & - & - & - & - \\
\hline Feature & LAB & & & & & & RAB & - & - & - & - \\
\hline $\begin{array}{l}\text { Low cord } \\
\text { elevation }\end{array}$ & 449.3 & 449.2 & 448.7 & 448.3 & 447.8 & 447.3 & 447.2 & - & - & - & - \\
\hline $\begin{array}{l}\text { Bed } \\
\text { elevation }\end{array}$ & 435.7 & 426.3 & 423.4 & 423 & 423.4 & 432.5 & 433.1 & - & - & - & - \\
\hline $\begin{array}{l}\text { Low cord to } \\
\text { bed length }\end{array}$ & 13.6 & 22.9 & 25.3 & 25.3 & 25.3 & 14.8 & 14.1 & - & - & - & - \\
\hline Station & - & - & - & - & - & - & - & - & - & - & - \\
\hline Feature & - & - & - & - & - & - & - & - & - & - & - \\
\hline $\begin{array}{l}\text { Low cord } \\
\text { elevation }\end{array}$ & - & - & - & - & - & - & - & - & - & - & - \\
\hline $\begin{array}{l}\text { Bed } \\
\text { elevation }\end{array}$ & - & - & - & - & - & - & - & - & - & - & - \\
\hline $\begin{array}{l}\text { Low cord to } \\
\text { bed length }\end{array}$ & - & - & - & - & - & - & - & - & - & - & - \\
\hline
\end{tabular}

Source (FEMA, VTAOT, Other)? VTAOT

Comments: Since the bridge is skewed to the channel, the VTAOT cross sections at the bridge are not reproducible and hence were not retrieved.

\begin{tabular}{|l|l|l|l|l|l|l|l|l|l|l|l|}
\hline Station & - & - & - & - & - & - & - & - & - & - & - \\
\hline Feature & - & - & - & - & - & - & - & - & - & - & - \\
\hline $\begin{array}{l}\text { Low cord } \\
\text { elevation }\end{array}$ & - & - & - & - & - & - & - & - & - & - & - \\
\hline $\begin{array}{l}\text { Bed } \\
\text { elevation }\end{array}$ & - & - & - & - & - & - & - & - & - & - & - \\
\hline $\begin{array}{l}\text { Low cord to } \\
\text { bed length }\end{array}$ & - & - & - & - & - & - & - & - & - & - & - \\
\hline Station & - & - & - & - & - & - & - & - & - & - & - \\
\hline Feature & - & - & - & - & - & - & - & - & - & - & - \\
\hline $\begin{array}{l}\text { Low cord } \\
\text { elevation }\end{array}$ & - & - & - & - & - & - & - & - & - & - & - \\
\hline $\begin{array}{l}\text { Bed } \\
\text { elevation }\end{array}$ & - & - & - & - & - & - & - & - & - & - & - \\
\hline $\begin{array}{l}\text { Low cord to } \\
\text { bed length }\end{array}$ & - & - & - & - & - & - & - & - & - & - & - \\
\hline
\end{tabular}




\section{APPENDIX E: \\ LEVEL I DATA FORM}


U. S. Geological Survey

Bridge Field Data Collection and Processing Form

Qa/Qc Check by: EW

Date: 10 /9/96

\section{Structure Number}

ROCKTH0001011R Computerized by: $\underline{\mathbf{E W}}$ Date: $\underline{\mathbf{1 0} / \mathbf{9} / 96}$

Reviewd by: $\quad$ EMB Date: 2/21/97

\section{A. General Location Descriptive}

1. Data collected by (First Initial, Full last name) E. BOEHMLER

Date $(M M / D D / Y Y) \underline{09} / \underline{03} / \underline{1996}$

2. Highway District Number $\mathbf{0 2}$

County Windsor (025)

Mile marker $\mathbf{0 0 3 3 6 0}$

Waterway (I - 6) Saxtons River

Route Number TH001

Town Rockingham (60250)

Road Name -

Hydrologic Unit Code: $\mathbf{0 1 0 8 0 1 0 7}$

3. Descriptive comments:

Located 4.1 miles west of the intersection of TH 1 with US route 5. This roadway also is labeled as State Route 121 and Federal Aid System Route 125.

\section{B. Bridge Deck Observations}
4. Surface cover... LBUS 2
RBUS 6
LBDS 4
RBDS 4
Overall 4

(2b us,ds,lb,rb: 1- Urban; 2- Suburban; 3- Row crops; 4- Pasture; 5- Shrub- and brushland; 6- Forest; 7- Wetland)
5. Ambient water surface... US 1
UB 1 DS 2
(1- pool; 2- riffle)

6. Bridge structure type 2 (1- single span; 2- multiple span; 3- single arch; 4- multiple arch; 5-cylindrical culvert; 6- box culvert; or 7- other)
7. Bridge length 184
(feet)
Span length 69
(feet)
Bridge width $\underline{39}$ (feet)

\section{Road approach to bridge:}
8. LB 2 RB 1
( 0 even, 1- lower, 2- higher)
9. $\mathrm{LB}$
RB 1
(1-Paved, 2- Not paved)

10. Embankment slope (run / rise in feet / foot)

US left --

US right --

\begin{tabular}{|c|c|c|c|}
\hline \multicolumn{2}{|c|}{ Protection } & \multirow{2}{*}{ 13.Erosion } & 14.Severity \\
\hline 11.Type & 12.Cond. & $\mathbf{0}$ & - \\
\hline $\mathbf{3}$ & $\mathbf{1}$ & $\mathbf{0}$ & - \\
$\mathbf{3}$ & $\mathbf{1}$ & $\mathbf{0}$ & - \\
\hline $\mathbf{3}$ & $\mathbf{1}$ & $\mathbf{0}$ & - \\
\hline $\mathbf{3}$ & $\mathbf{1}$ & $\mathbf{0}$ & - \\
\hline
\end{tabular}

Bank protection types: 0- none; 1- < 12 inches,

2- < 36 inches; 3- < 48 inches;

4- < 60 inches; 5- wall / artificial levee

Bank protection conditions: 1- good; 2- slumped;

3- eroded; 4- failed

Erosion: 0 - none; 1- channel erosion; 2 -

road wash; 3- both; 4- other

Erosion Severity: 0 - none; 1- slight; 2- moderate; 3- severe

\section{Channel approach to bridge (BF):}

15. Angle of approach: $\mathbf{5}$

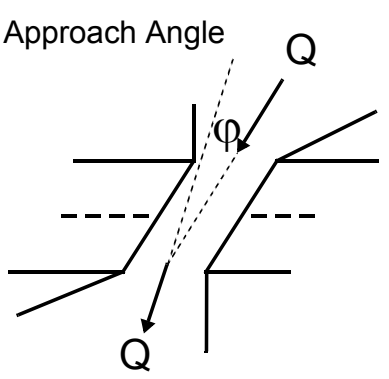

17. Channel impact zone 1 :

Where? LB $(L B, R B)$

Range? 200 feet $\underline{\text { US }}$

Channel impact zone 2:

Where? RB (LB, RB)

Range? 20 feet $\underline{\mathbf{U B}}$ (US, UB, DS) to $\underline{95}$ feet $\underline{\mathbf{D S}}$

Impact Severity: 0- none to very slight; 1- Slight; 2- Moderate; 3- Severe
16. Bridge skew: 35 Bridge Skew Angle

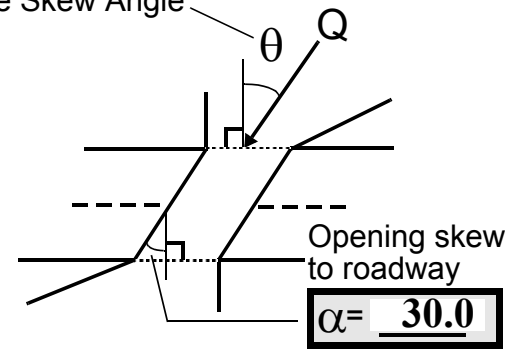

\section{Exist? $\underline{\mathbf{Y}}(\mathrm{Y}$ or $N)$}

Severity 1

(US, UB, DS) to 100 feet $\underline{\mathbf{U S}}$

Exist? $\mathbf{Y}(Y$ or $N)$

Severity 1 
18. Bridge Type: $\mathbf{3}$

1a- Vertical abutments with wingwalls

1 b- Vertical abutments without wingwalls

2- Vertical abutments and wingwalls, sloping embankment Wingwalls perpendicular to abut. face

3- Spill through abutments

4- Sloping embankment, vertical wingwalls and abutments

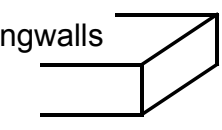

1 a with wingwalls

Wingwall angle less than $90^{\circ}$.
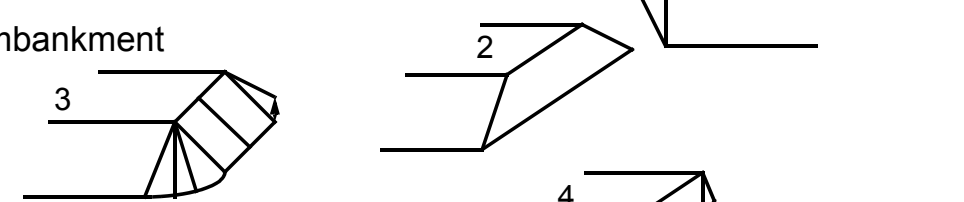

19. Bridge Deck Comments (surface cover variations, measured bridge and span lengths, bridge type variations, approach overflow width, etc.)

USRB coverage is forest with a strip of grass and brush land bisecting trees on immediate bank and forest on valley wall. USLB has trees and brush along immediate bank with houses and lawn on overbank for entire 300 feet or so up LB side. RBDS coverage is also lawn with a house and tree cover on immediate bank. DSLB cover is also lawn with a house and tree cover on immediate bank. Between 0 feet downstream and 100 feet downstream on LOB is tree cover.

Bridge dimensions measured in field were the same as historical form values.

\section{Upstream Channel Assessment}

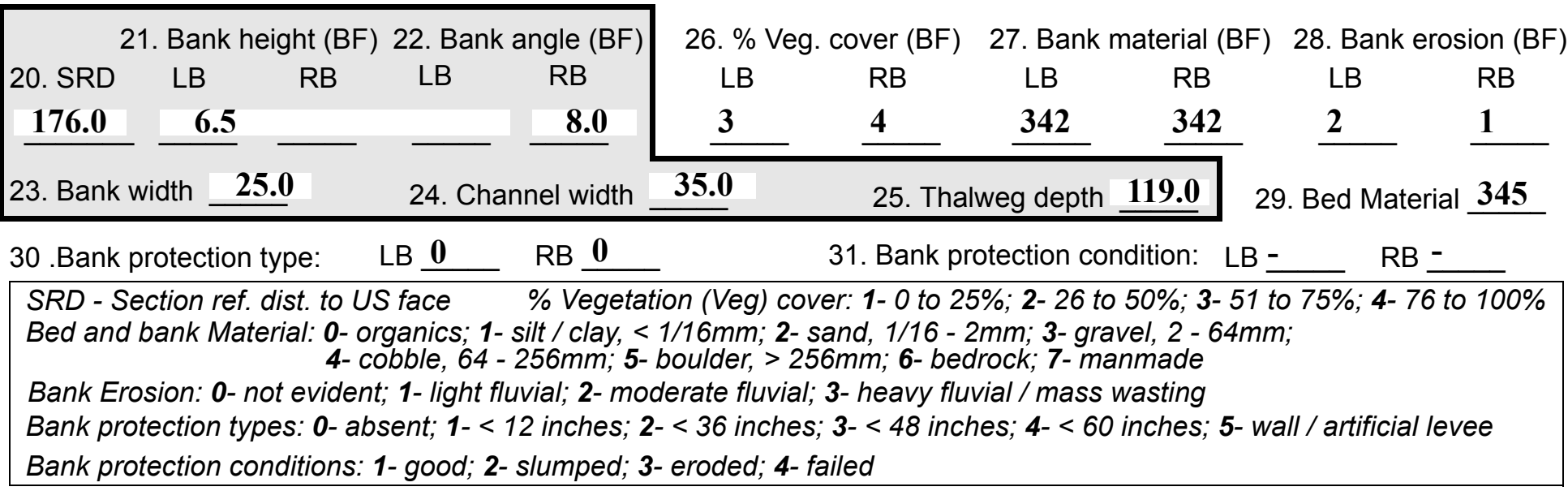

32. Comments (bank material variation, minor inflows, protection extent, etc.):

The channel upstream flows along the LB side. The LB is cut and there is a point bar along the RB side. The channel gradient upstream is moderate and steady. The water surface at this stage is riffle along the side of the point bar and is pooled beyond 400 feet upstream. There is a third point bar upstream on LB extending from 450 feet upstream to 370 feet upstream on $\mathrm{LB}$; it is composed of gravel and cobbles at its upstream end, and grades to sand at its downstream end. The point bar is located at an old bridge crossing where abutments still exist, but deck does not. 
36. Point bar extent: $\underline{395}$ feet $\underline{\text { US }}$ (US, UB) to $\underline{\mathbf{3 5}}$ feet DS (US, UB, DS) positioned $\underline{\mathbf{4 0}} \%$ LB to $100 \% \mathrm{RB}$

37. Material: 435

38. Point or side bar comments (Circle Point or Side; Note additional bars, material variation, status, etc.):

The point bar is long and high, approximately 2.5 to 3 feet higher along crest of point bar material. The point bar is about $20 \%$ vegetation covered with more coverage and older growth coverage mainly at downstream end of the bar. Vegetation at upstream end of bar has been swept over by a recent high flow event.

\section{Is a cut-bank present? Y (Y or if $N$ type ctrl-n cb) 40. Where? LB (LB or RB)}

41. Mid-bank distance: $240 \quad$ 42. Cut bank extent: $\underline{\mathbf{3 0 0}}$ feet $\underline{\mathrm{US}}$ (US, UB) to $\underline{\mathbf{5}}$ feet $\underline{\text { US }}$ (US, UB, DS)

43. Bank damage: 2 (1-eroded and/or creep; 2- slip failure; 3- block failure)

44. Cut bank comments (eg. additional cut banks, protection condition, etc.):

Near mid-bank, there are water swept young trees and shrubs that have fallen over in flow direction or are leaning in the direction of flow. The thin soil layer present on top of bank material has a ragged edge and overhangs the bank material below. The bank material has slipped down on the bank slope in places, leaving the soil layer on top overhanging. The bank ends where the stone fill abutment slope begins.

45. Is channel scour present? $\mathbf{N}$ (Yor if $N$ type ctrl-n cs) 46. Mid-scour distance: -
47. Scour dimensions: Length - Width -
Depth : -
Position - $\%$ LB to - $\%$ RB

48. Scour comments (eg. additional scour areas, local scouring process, etc.):

NO CHANNEL SCOUR

49. Are there major confluences? $\mathbf{N}$

51. Confluence 1: Distance Confluence 2: Distance 52. Enters on Enters on 54. Confluence comments (eg. confluence name):

NO MAJOR CONFLUENCES
(Y or if $N$ type ctrl-n $m c)$ ( $L B$ or $R B)$ (LB or $R B)$
50. How many? -

53. Type(1- perennial; 2- ephemeral)

Type (1- perennial; 2- ephemeral)

NO MAJOR CONFLUENCES

\section{Under Bridge Channel Assessment}

55. Channel restraint (BF)? LB 2

56. Height (BF)
LB RB
$\mathbf{1 1 0 . 5}-$
58. Bank width (BF) =

59. Channel width $(A m b)$

61. Material (BF)

LB RB

$\underline{\mathbf{5}} \underline{\mathbf{5}}$

(1- natural bank; 2- abutment; 3- artificial levee)

Bed and bank Material: 0- organics; 1- silt / clay, < 1/16mm; 2- sand, 1/16 - 2mm; 3- gravel, 2 - 64mm; 4- cobble, 64 - 256mm; 5- boulder, > 256mm; 6- bedrock; 7- manmade

Bank Erosion: 0- not evident; 1- light fluvial; 2- moderate fluvial; 3- heavy fluvial / mass wasting

64. Comments (bank material variation, minor inflows, protection extent, etc.):

345

The channel gradient upstream becomes flatter and the water surface pools at this stage from 65 feet upstream to 35 feet under bridge. Both abutments are concrete walls with type 2 stone fill spill-through slopes from the walls to the channel bed. The LB cut-bank upstream ends where the spill-through abutment slope intersects the bank about 85 feet upstream. The bank cutting near this intersection area has not damaged the spill-through slope as slumping or other evidence of erosion of stone fill is not evident. The channel width shown above is the distance between the toe of each spill-through embankment. 
65. Debris and Ice Is there debris accumulation? (Yor $N)$ 66. Where? $\mathbf{N}$ (1- Upstream; 2- At bridge; 3- Both)

67. Debris Potential (1-Low; 2- Moderate; 3- High) 68. Capture Efficiency 2 (1-Low; 2- Moderate; 3- High) 69. Is there evidence of ice build-up? 1 (Y or N) Ice Blockage Potential $\underline{\mathbf{Y}}$ (1-Low; 2-Moderate; 3- High)

70. Debris and Ice Comments:

1

There is some minor debris (sticks, twigs and leaves) caught in tree limbs on upstream point bar. These trees and those at the downstream end of LB cut-bank upstream have been scarred by ice. Trees and shrubs on the point bar and cut-bank are damaged and may be stripped from the bar or bank by subsequent high flow events. The piers are off to the sides of the channel. The left pier would have the greatest tendency to

\begin{tabular}{|c|c|c|c|c|c|c|c|c|}
\hline Abutments & $\begin{array}{c}\text { 71. Attack } \\
\angle(B F)\end{array}$ & $\begin{array}{l}\text { 72. Slope } \angle \\
\text { (Qmax) }\end{array}$ & $\begin{array}{l}\text { 73. Toe } \\
\text { loc. (BF) }\end{array}$ & $\begin{array}{l}\text { 74. Scour } \\
\text { Condition }\end{array}$ & $\begin{array}{l}\text { 75. Scour } \\
\text { depth }\end{array}$ & $\begin{array}{c}\text { 76. Exposure } \\
\text { depth }\end{array}$ & 77. Material & 78. Length \\
\hline LABUT & cap- & ture & debr & is as & flow & impa & cts it & 90.0 \\
\hline RABUT & muc & h & more & & & so & than & 174.5 \\
\hline
\end{tabular}

Pushed: $L B$ or RB

Toe Location (Loc.): 0- even, 1- set back, 2- protrudes

Scour cond.: 0- not evident; 1- evident (comment); 2- footing exposed; 3-undermined footing; 4- piling exposed; 5- settled; 6- failed

Materials: 1- Concrete; 2- Stone masonry or drywall; 3- steel or metal; 4- wood

79. Abutment comments (eg. undermined penetration, unusual scour processes, debris, etc.):

the right pier.

40

0

0

2

5

35

80. Wingwalls:

Exist? Material? Scour Scour Exposure Angle? Length? Condition? depth? depth?

USLWW: 0

0

USRWW: -

$+$

DSLWW: 2

DSRWW: slope Conger 105.5

Wingwall materials: 1- Concrete; 2- Stone masonry or drywall; 3- steel or metal; 4- wood

2

thro

on

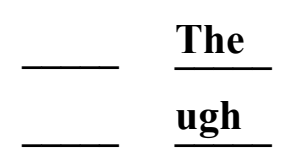

RAB

52.5

82. Bank / Bridge Protection:

\begin{tabular}{|l|l|l|l|l|l|l|l|l|}
\hline Location & USLWW & USRWW & LABUT & RABUT & LB & RB & DSLWW & DSRWW \\
\hline Type & UT & sta- & the & the & alm & belo & base & $\mathbf{9 0}$ \\
\hline Condition & app & ble, & top & slop & ost 1 & w & of & degr \\
\hline Extent & ears & but & of & e is & foot & the & the & ee \\
\hline
\end{tabular}

Bank / Bridge protection types: 0- absent; 1- < 12 inches; 2- < 36 inches; 3- < 48 inches; 4- < 60 inches; 5- wall / artificial levee

Bank / Bridge protection conditions: 1- good; 2- slumped; 3- eroded; 4- failed

Protection extent: 1- entire base length; 2- US end; 3- DS end; 4- other 
83. Wingwall and protection comments (eg. undermined penetration, unusual scour processes, etc.):

concrete wall as a result of the skeleton type concrete abutment. Both concrete abutment walls are vertical skeleton style walls. The back of the wall may be seen underneath.

$\mathbf{N}$

Piers:

84. Are there piers? _ _ (Y or if $N$ type ctrl-n pr)

\begin{tabular}{|l|l|l|l|l|l|l|l|}
\hline \multirow{2}{*}{$\begin{array}{l}85 . \\
\text { Pier no. }\end{array}$} & \multicolumn{3}{|c|}{ width (w) feet } & \multicolumn{3}{c|}{ elevation (e) feet } \\
\cline { 2 - 8 } & w1 & w2 & w3 & e@w1 & e@w2 & e@w3 \\
\hline Pier 1 & - & - & - & - & - & - \\
\hline Pier 2 & - & $\mathbf{2 . 5}$ & $\mathbf{5}$ & - & - & - \\
\hline Pier 3 & - & $\mathbf{2 . 5}$ & $\mathbf{5}$ & - & - & - \\
\hline Pier 4 & - & - & - & - & - & - \\
\hline
\end{tabular}

\begin{tabular}{|c|c|c|c|c|}
\hline Level 1 Pier Descr. & 1 & 2 & 3 & 4 \\
\hline 86. Location (BF) & - & $\mathbf{N}$ & 1 & - \\
\hline 87. Type & - & - & 1 & - \\
\hline 88. Material & $\mathbf{N}$ & - & 3 & - \\
\hline 89. Shape & - & - & 1 & - \\
\hline 90. Inclined? & - & - & 1 & - \\
\hline 91. Attack $\angle(\mathrm{BF})$ & - & - & - & No \\
\hline 92. Pushed & - & - & - & wing \\
\hline 93. Length (feet) & - & - & - & - \\
\hline 94. \# of piles & $\mathbf{N}$ & - & - & walls \\
\hline 95. Cross-members & - & - & - & exist \\
\hline 96. Scour Condition & - & - & - & s. \\
\hline 97. Scour depth & - & - & - & Pro- \\
\hline 98. Exposure depth & - & 3 & - & tec- \\
\hline
\end{tabular}

LFP, LTB, LB, MCL, MCM, MCR, RB, RTB, RFP

1- Solid pier, 2- column, 3- bent

1- Wood; 2- concrete; 3- metal; 4- stone

1- Round; 2- Square; 3- Pointed

Y-yes; $N$ - no

$L B$ or $R B$

0- none; 1- laterals; 2- diagonals; 3- both

0- not evident; 1- evident (comment);

2- footing exposed; 3- piling exposed;

4- undermined footing; 5- settled; 6- failed 
99. Pier comments (eg. undermined penetration, protection and protection extent, unusual scour processes, etc.):

tion from abutment slopes wraps around ends of abutments at all four corners of structure.

100.

\section{E. Downstream Channel Assessment}

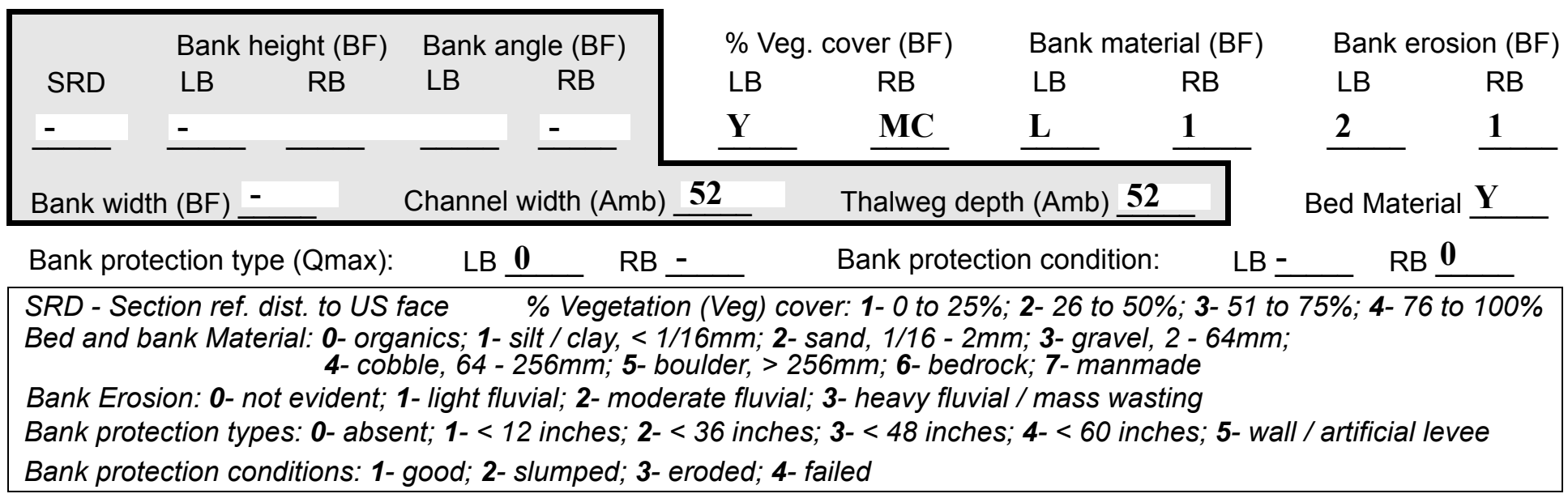

Comments (eg. bank material variation, minor inflows, protection extent, etc.):

2

4.5

1.0

MCR

1

2

1

Y

5

RB

$-$

0

1

1.5

0

101. Is a drop structure present? ___ ( $Y$ or $N$, if $N$ type ctrl-n ds) 102. Distance: ___ feet
103. Drop: - feet
104. Structure material:
(1- steel sheet pile; 2- wood pile; 3- concrete; 4- other)

105. Drop structure comments (eg. downstream scour depth): 
106. Point/Side bar present? (Y or N. if $N$ type ctrl-n pb)Mid-bar distance:

Mid-bar width:

Point bar extent: feet (US, UB, DS) to feet (US, UB, DS) positioned $\%$ LB to $\% \mathrm{RB}$

Material:

Point or side bar comments (Circle Point or Side; note additional bars, material variation, status, etc.):

Is a cut-bank present? ( $Y$ or if $N$ type ctrl-n $c b) \quad$ Where? (LB or $R B)$

Mid-bank distance: $\underline{\text { The }}$

Cut bank extent: re is feet no (US, UB, DS) to stone feet fill (US, UB, DS)

Bank damage: pro (1-eroded and/or creep; 2- slip failure; 3- block failure)

Cut bank comments (eg. additional cut banks, protection condition, etc.):

tection on pier 2. A small scour hole is evident at the downstream end of pier 2 , primarily on the left side. The hole is 33 feet long beginning 13 feet upstream from the downstream end of pier to 20 feet downstream of pier. It is 7 feet wide along pier edge and 1.5 feet deep (ambient thalweg is 1 foot). There is some protection on bed at upstream end of pier 1 mainly on the LABUT side of the pier. Footing is

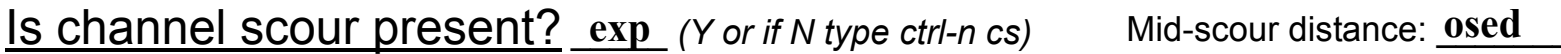
Scour dimensions: Length 1 Width foot Depth: $\underline{\text { at }}$

Positioned nos \%LB to e to \%RB

Scour comments (eg. additional scour areas, local scouring process, etc.):

flush with adjacent streambed along mid-span side of pier for 8 feet from upstream end. Scour hole extends from 25 feet upstream of pier 1 to 20 feet along right side of pier and 12 feet along LABUT side of pier. The hole is 4.5 feet at most below ambient thalweg depth. The hole extends 4 feet from the left side of the pier and about 8 feet from the right side of the pier toward the middle of the channel. Piers are inclined since the length

Are there major confluences? is ( $Y$ or if $N$ type ctrl-n mc)

How many? 47

Confluence 1: Distance feet

Enters on at (LB or $R B)$

Type the

(1-perennial; 2- ephemeral)

Confluence 2: Distance top

Enters on and (LB or $R B)$

Type $\mathbf{5 2}$ (1-perennial; 2- ephemeral)

Confluence comments (eg. confluence name):

feet at base.

\section{F. Geomorphic Channel Assessment}

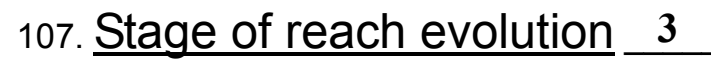

1- Constructed

2- Stable

3- Aggraded

4- Degraded

5- Laterally unstable

6- Vertically and laterally unstable 
108. Evolution comments (Channel evolution not considering bridge effects; See HEC-20, Figure 1 for geomorphic descriptors):

3

342

342

0

1

345

0

0

-

The channel downstream has a moderately sloping and steady gradient. The water surface at this stage is riffle from about 10 feet under the bridge (from the downstream face) to about $\mathbf{2 8 0}$ feet downstream, where channel makes a 70 degree turn to the right at a bedrock outcrop, which makes up the left bank. 


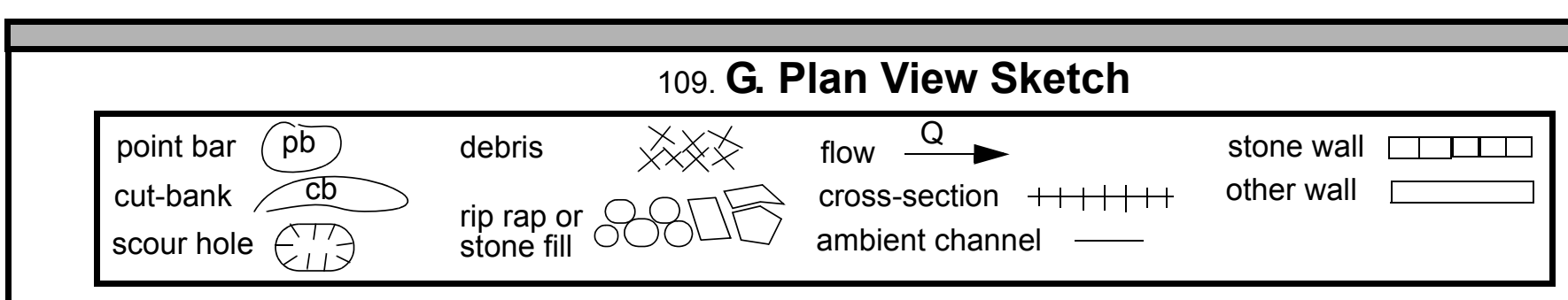

Fr 
APPENDIX F:

SCOUR COMPUTATIONS 
SCOUR COMPUTATIONS

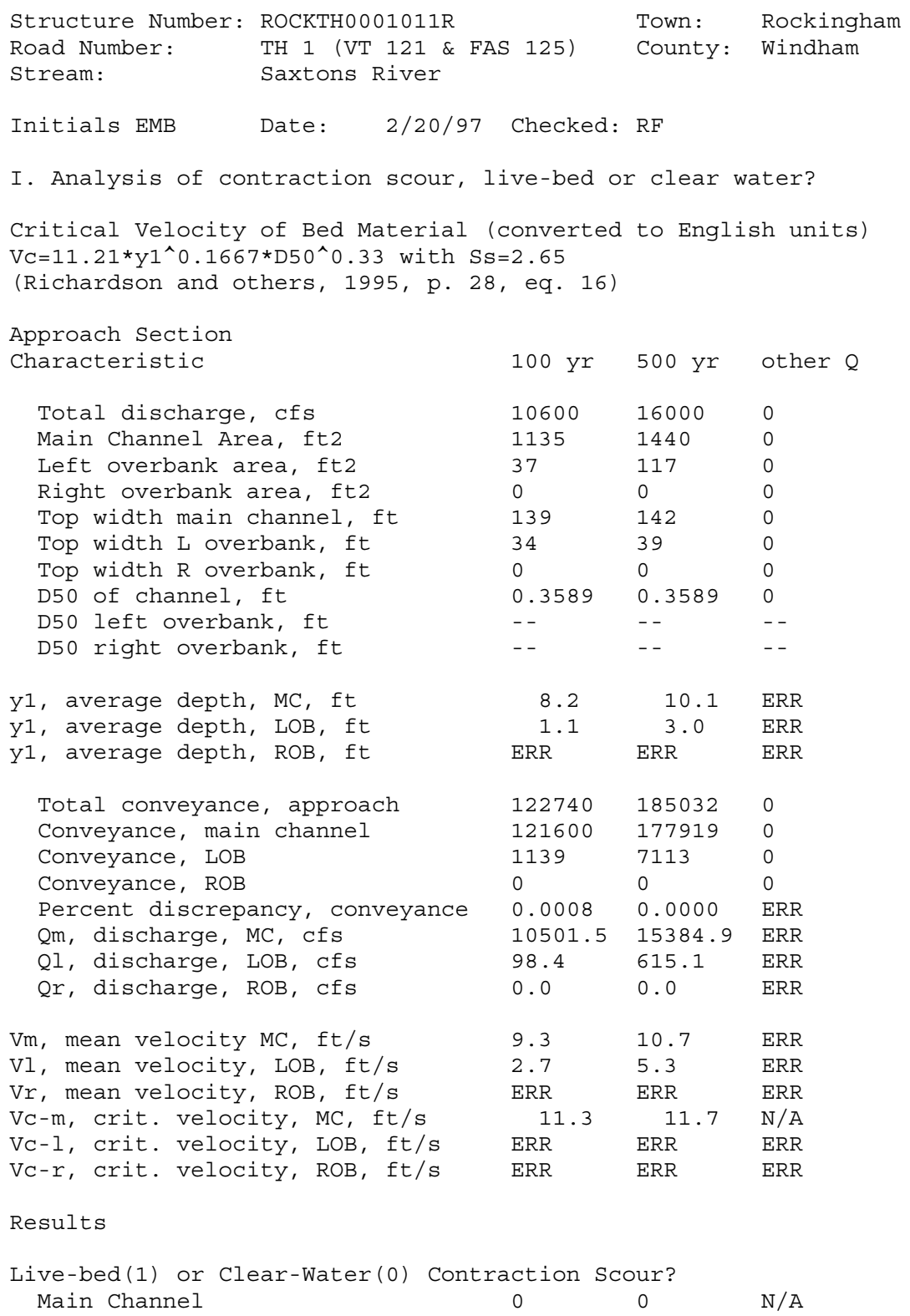


Clear water Contraction Scour in MAIN CHANNEL

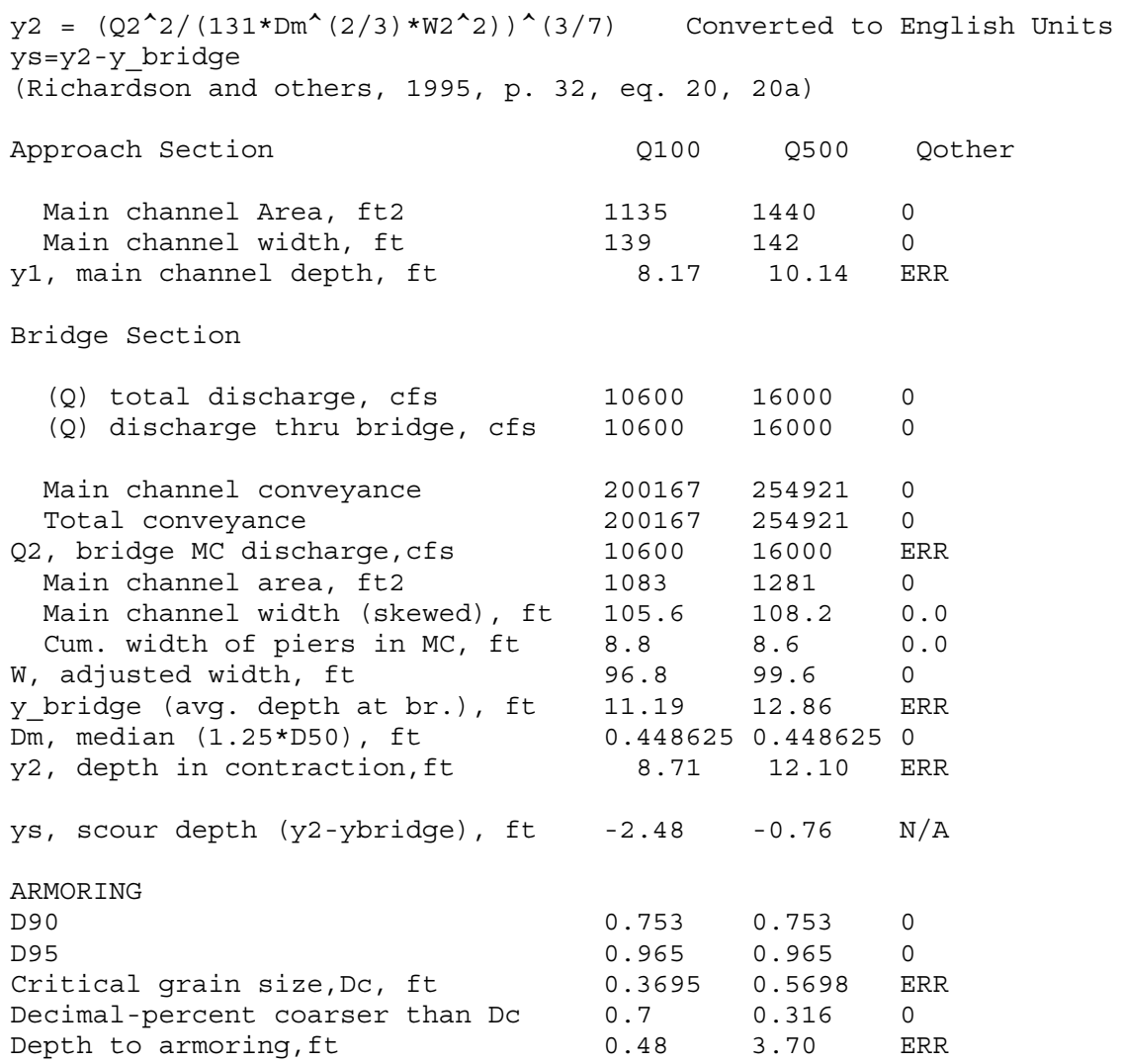




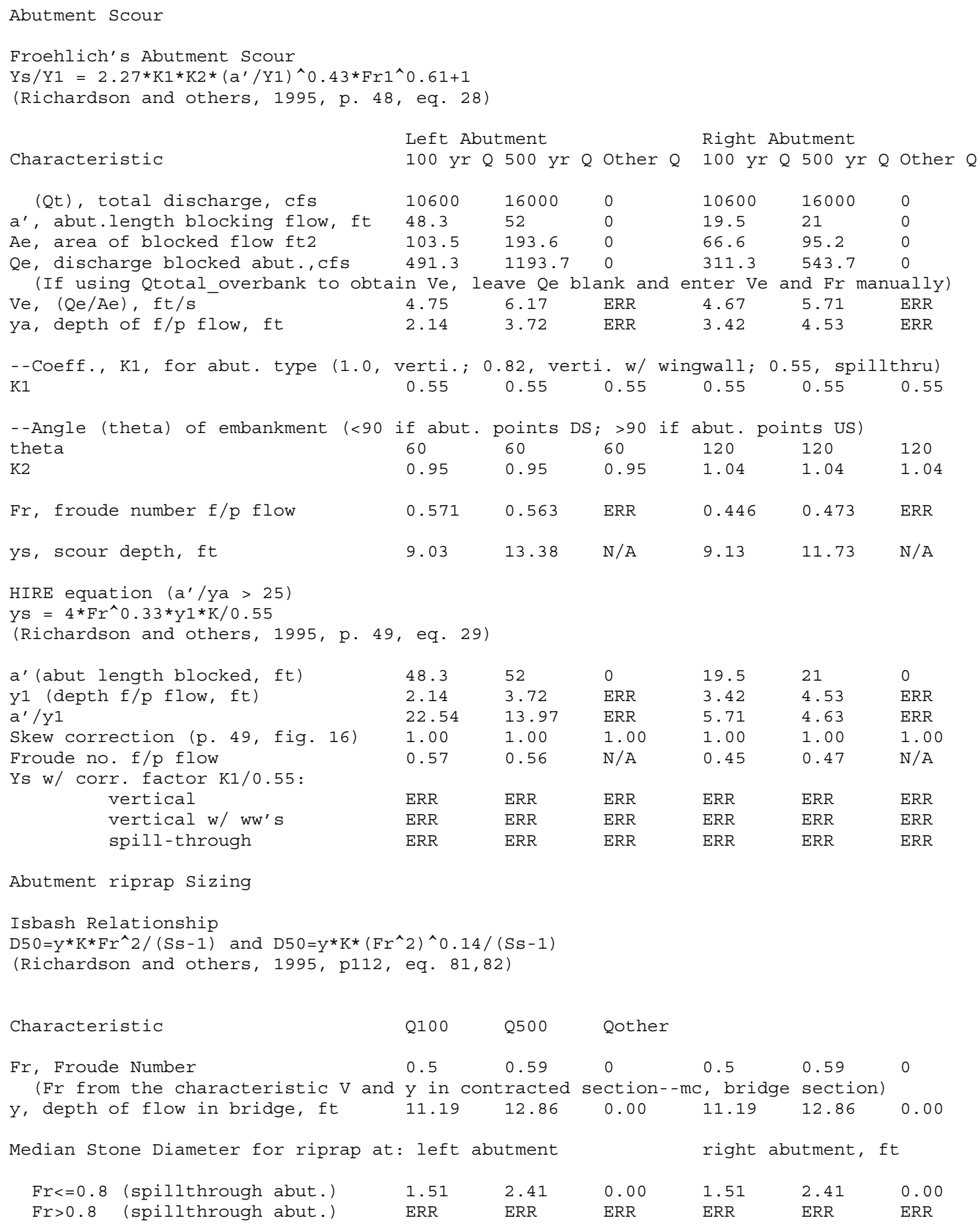




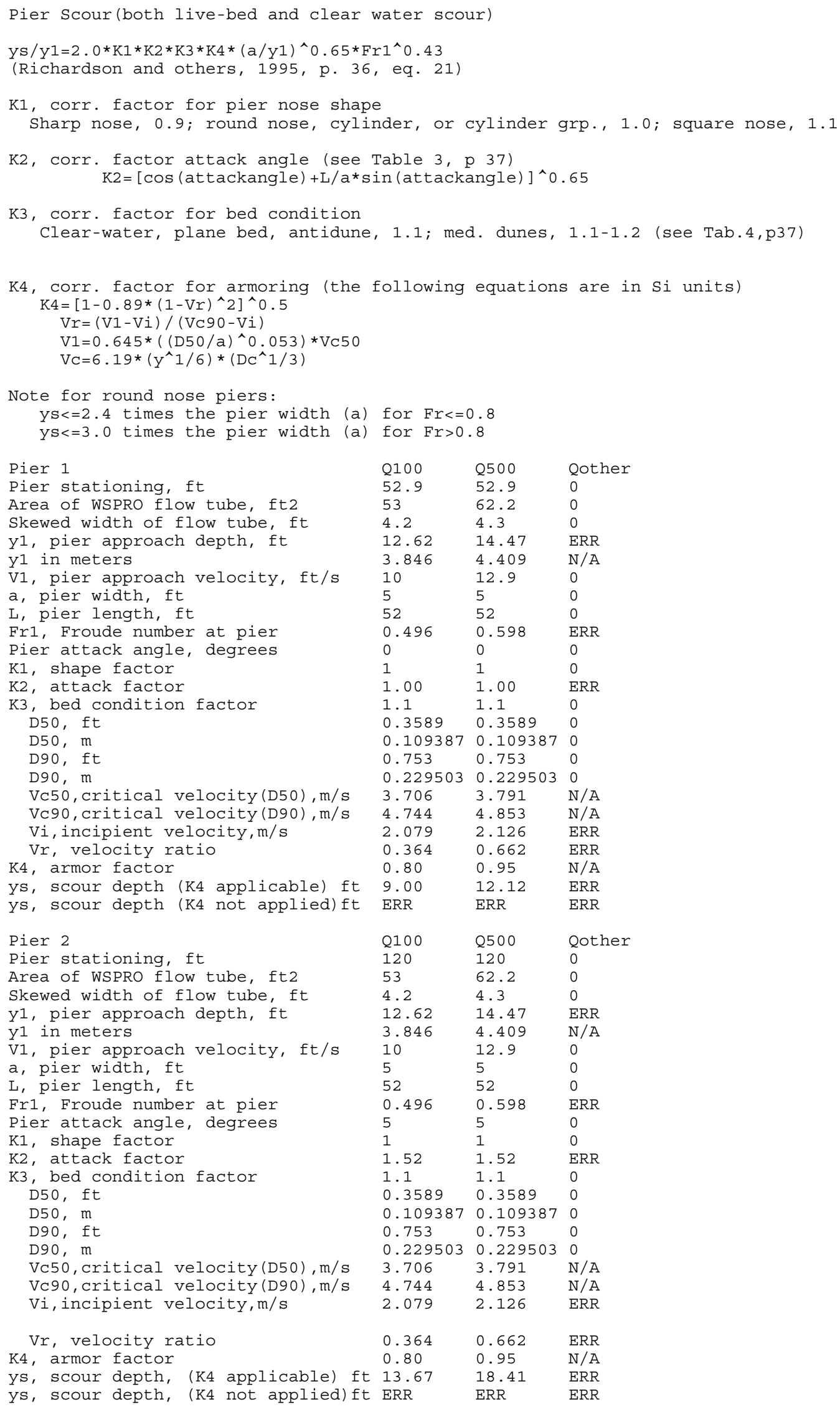

\begin{tabular}{|c|c|c|}
\hline Q100 & Q500 & Qother \\
\hline 52.9 & 52.9 & 0 \\
\hline 53 & 62.2 & 0 \\
\hline 4.2 & 4.3 & 0 \\
\hline 12.62 & 14.47 & ERR \\
\hline 3.846 & 4.409 & $\mathrm{~N} / \mathrm{A}$ \\
\hline 10 & 12.9 & 0 \\
\hline 5 & 5 & 0 \\
\hline 52 & 52 & 0 \\
\hline 0.496 & 0.598 & ERR \\
\hline 0 & 0 & 0 \\
\hline 1 & 1 & 0 \\
\hline 1.00 & 1.00 & ERR \\
\hline 1.1 & 1.1 & 0 \\
\hline 0.3589 & 0.3589 & 0 \\
\hline 0.109387 & 0.109387 & 0 \\
\hline 0.753 & 0.753 & 0 \\
\hline 0.229503 & 0.229503 & 0 \\
\hline 3.706 & 3.791 & $\mathrm{~N} / \mathrm{A}$ \\
\hline 4.744 & 4.853 & $\mathrm{~N} / \mathrm{A}$ \\
\hline 2.079 & 2.126 & ERR \\
\hline 0.364 & 0.662 & ERR \\
\hline 0.80 & 0.95 & $\mathrm{~N} / \mathrm{A}$ \\
\hline 9.00 & 12.12 & ERR \\
\hline ERR & ERR & ERR \\
\hline Q100 & Q500 & Qother \\
\hline 120 & 120 & 0 \\
\hline 53 & 62.2 & 0 \\
\hline 4.2 & 4.3 & 0 \\
\hline 12.62 & 14.47 & ERR \\
\hline 3.846 & 4.409 & $\mathrm{~N} / \mathrm{A}$ \\
\hline 10 & 12.9 & 0 \\
\hline 5 & 5 & 0 \\
\hline 52 & 52 & 0 \\
\hline 0.496 & 0.598 & ERR \\
\hline 5 & 5 & 0 \\
\hline 1 & 1 & 0 \\
\hline 1.52 & 1.52 & ERR \\
\hline 1.1 & 1.1 & 0 \\
\hline 0.3589 & 0.3589 & 0 \\
\hline 0.109387 & 0.109387 & 0 \\
\hline 0.753 & 0.753 & 0 \\
\hline 0.229503 & 0.229503 & 0 \\
\hline 3.706 & 3.791 & $\mathrm{~N} / \mathrm{A}$ \\
\hline 4.744 & 4.853 & $\mathrm{~N} / \mathrm{A}$ \\
\hline 2.079 & 2.126 & ERR \\
\hline 0.364 & 0.662 & ERR \\
\hline 0.80 & 0.95 & $\mathrm{~N} / \mathrm{A}$ \\
\hline 13.67 & 18.41 & ERR \\
\hline ERR & ERR & ERR \\
\hline
\end{tabular}


$\mathrm{D} 50=0.692(\mathrm{~K} * \mathrm{~V}){ }^{\wedge} 2 /(\mathrm{Ss}-1) * 2 * \mathrm{~g}$

(Richardson and others, 1995, p.115, eq. 83)

Pier-shape coefficient $(\mathrm{K})$, round nose, 1.5 ; square nose, 1.7 Characteristic avg. channel velocity, V, (Q/A):

(Mult. by 0.9 for bankward piers in a straight, uniform reach, up to 1.7 for a pier in main current of flow around a bend)

$\begin{array}{llll}\text { Pier 1 } & \text { Q100 } & \text { Q500 } & \text { Qother } \\ \text { K, pier shape coeff. } & 1.5 & 1.5 & 0 \\ \text { V, char. aver. velocity, ft/s } & 9.8 & 12.5 & 0 \\ \text { D50, median stone diameter, ft } & 1.41 & 2.29 & 0.00 \\ \text { Pier 2 } & & & 0 \\ \text { K, pier shape coeff. } & 1.5 & 1.5 & 0 \\ \text { V, char. aver. velocity, ft/s } & 9.8 & 12.5 & 0.00 \\ \text { D50, median stone diameter, ft } & 1.41 & 2.29 & \end{array}$

